\title{
Geophysical characterization of late-Quaternary glaciofluvial complex and glacial stratigraphy in the Satakunta sandstone area, Köyliö, southwest Finland
}

Elina Marita Ahokangas ${ }^{1 *}$ (D), Georgiana Anca Maries ${ }^{2}$, Joni Kalevi Mäkinen¹, Antti Heikki Pasanen ${ }^{3}$, Alireza Malehmir², Suvi Elina Heinonen ${ }^{4}$, Matti Ensio Pajunen ${ }^{5}$

${ }^{1}$ Department of Geography and Geology, University of Turku, FI-20014 TURUN YLIOPISTO, Finland

2 Department of Earth Sciences, Uppsala University, Villavägen 16, SE-75236 UPPSALA, Sweden

${ }^{3}$ Geological Survey of Finland, P.O Box 1237, FI-70211 KUOPIO, Finland

${ }^{4}$ Geological Survey of Finland, P.O. Box 96, FI-02151 ESPOO, Finland

${ }^{5}$ Kasalantie 314, FI-64490 SIIPYY, Finland

* Corresponding author at: Email address: eliaho@utu.fi (E.M. Ahokangas).

(RECEIVED February 25, 2020; ACCEPTED July 29, 2020)

\begin{abstract}
We acquired high-resolution reflection seismic data using a broadband digital-based landstreamer system to characterize a depression related to the Mesoproterozoic (Jothnian) Satakunta sandstone basin in the Köyliö study area, southwest Finland. This ca. 800-m-wide depression is infilled with up to 100-m-thick (late) Quaternary interlobate glaciofluvial complex sediments. The seismic images clearly reveal details of the glaciofluvial complex, sandstone depression topography, and brittle structures related to the formation of the sandstone basin by oblique transtension. Additionally, we identified the setting of a diabase laccolith within the sandstone and the geometry and position of the steep sandstone contact. The esker core does not follow the sandstone-Svecofennian basement rock contact or lean to it. The esker core is at a depth of 50-60 m on the flank of the depression. The seismic data image the esker core and other architectural elements of the esker. We highlight the potential of the digital-based landstreamer in the research of complex Quaternary sediments in major bedrock depressions including the characterization of the underlying bedrock properties. We also discuss the possible tunnel valley origin of the sandstone depression.
\end{abstract}

Key words: Esker architecture; Finland; Geophysical methods; Landstreamer; Sandstone depression; Seismic stratigraphy

\section{INTRODUCTION}

Interlobate eskers represent one of the largest glaciofluvial landforms and can have sediments up to $100 \mathrm{~m}$ thick. They form between two ice lobes with different ice dynamics (Punkari, 1980; Lundqvist, 1989; Kujansuu et al., 1995; Brennand and Shaw, 1996; Thomas and Montaque, 1997; Gruszka et al., 2012; Santos, 2012). Interlobate glaciofluvial complexes may have highly varying internal structures due to variable sedimentation patterns and rapid changes in depositional processes and environments (Paterson and Cheel, 1997; Russell and Arnott, 2003; Mäkinen, 2004).

Cite this article: Ahokangas, E. M., Maries, G. A., Mäkinen, J. K., Pasanen, A. H., Malehmir, A., Heinonen, S. E., Pajunen, M. E. 2021. Geophysical characterization of late-Quaternary glaciofluvial complex and glacial stratigraphy in the Satakunta sandstone area, Köyliö, southwest Finland. Quaternary Research 100, 135-153. https://doi.org/10.1017/ qua.2020.77
Although morphologically varying, long and continuous glaciofluvial deposits, including fan deposits, are generally referred to as eskers (cf. Mäkinen, 2003a); here we use the term glaciofluvial complex. This includes several glaciofluvial elements including the esker with its commonly boulderrich esker core, subaqueous outwash fans, morphologically undetectable kettle holes (MUKHs), and ice-marginal crevasse deposits as described by Mäkinen (2003b) for the Säkylänharju-Virttaankangas glaciofluvial complex located within the same interlobate system as the one studied here. The significance of these large landforms to society is great as they host significant ground water resources and sand and gravel deposits (Ahokangas, 2019). In the Köyliö area, southwest Finland, the esker chain has been mapped (Lindroos et al., 1983) to follow the sandstone-Svecofennian basement rock contact in the deep Satakunta sandstone depression (Fig. 1). According to Lindroos and colleagues (1983), the esker core lies on to the sandstone-Svecofennian basement 


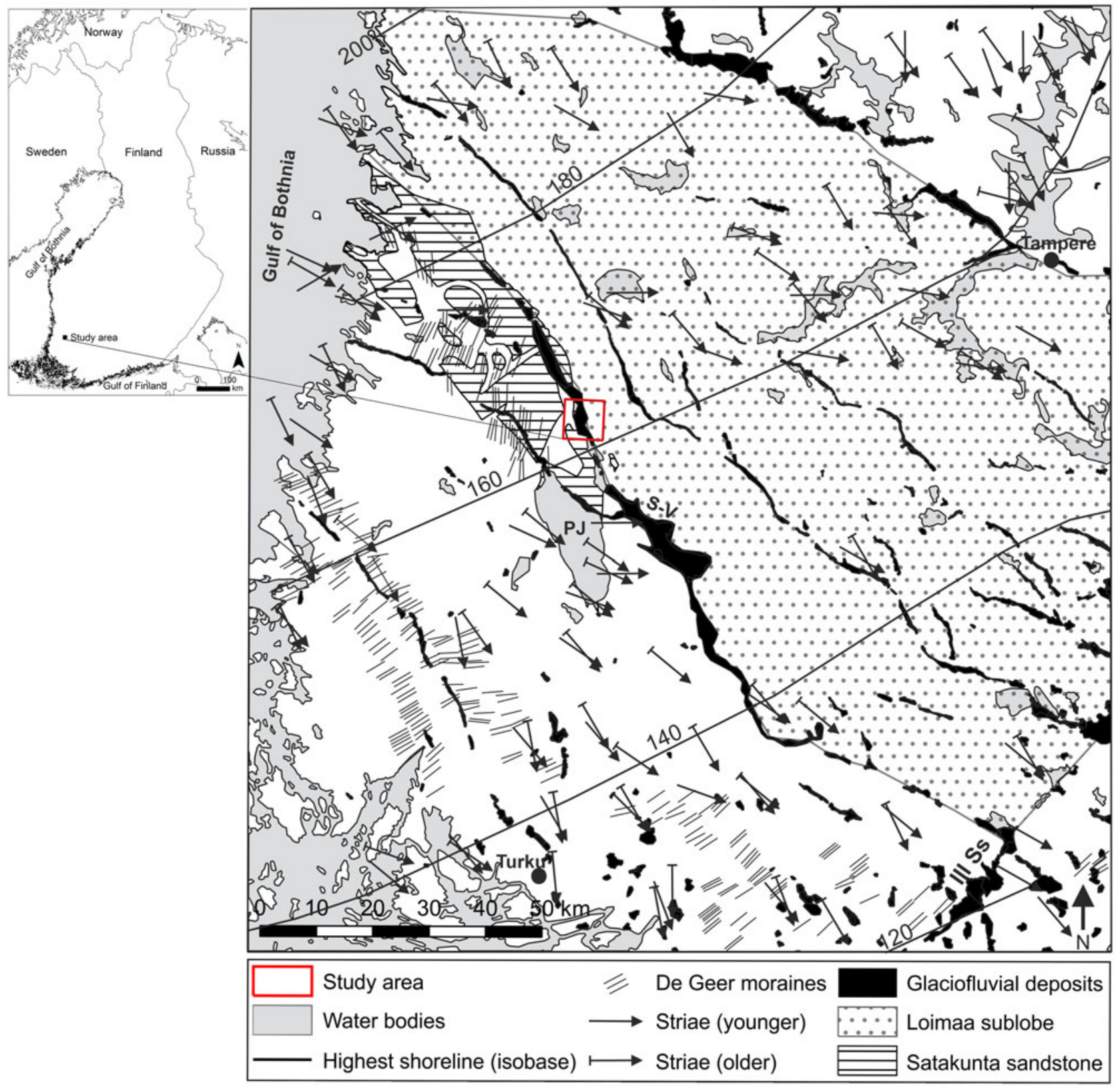

Figure 1. The location of the Köyliö study area in southwest Finland (small index map) with the Loimaa sublobe, striae (younger and older), De Geer moraines, and Satakunta sandstone () Geological Survey of Finland. Cities, lake bodies, and Baltic Sea ( National Land Survey of Finland. The classified ground water areas (eskers) (C Finnish Environment Center. III Ss: Third Salpausselkä end moraine, PJ: Lake Pyhäjärvi, S-V: Säkylänharju-Virttaankangas glaciofluvial complex.

contact, which results in an asymmetric core form in the southeastern side of Lake Köyliönjärvi. Locally over $90 \mathrm{~m}$ of glaciofluvial sediments fill this ca. 200-1000-m-wide and up to 20-km-long depression (Palmu et al., 1994).

Large interlobate glaciofluvial complexes completely filling bedrock depressions are uncommon in both Finland and elsewhere. Eskers in southern Finland usually directly overlie the crystalline Paleoproterozoic Svecofennian bedrock (>1800 Ma), but in Köyliö they overlie Mesoproterozoic sandstone. This is unusual as Mesoproterozoic sedimentary rocks are rare in Finland. The known occurrences are poorly exposed and have been preserved in bedrock depressions mainly filled with Quaternary sediments or in areas with low glacial erosion. Similar settings elsewhere in Finland are buried by glaciofluvial and glacial sediments that can be up to $100 \mathrm{~m}$ thick like in the Suupohja area adjacent to the Lauhanvuori Sandstone Formation (Pitkäranta, 2009) and $140 \mathrm{~m}$ thick like in the Neo-Proterozoic Jothnian Muhos Formation in the Oulu district (cf. Breilin et al., 2006; Breilin and Putkinen, 2012). Moreover, the dimensions of the Satakunta sandstone depression are within the range of known tunnel valley dimensions (Ó Cofaigh, 1996; Praeg, 2003; Gibling, 
2006; Kristensen et al., 2007). However, the Köyliö glaciofluvial complex seems to completely fill the depression, whereas tunnel valleys often have eskers running at the bottom while the rest of the valley is usually infilled with other types of sediments (Ó Cofaigh, 1996; Brennand et al., 2006). The Köyliö area also lacks the overlying fine-grained deposits or overlying/interbedded till deposits that have been found in several Canadian (Ahmad et al., 2009; Pugin et al., 2009, 2014a), North American (Clayton et al., 1999; Hooke and Jennings, 2006), and European tunnel valley systems (Huuse et al., 2003; Jørgensen and Sandersen, 2006; Kristensen et al., 2007). The evolution of the sandstone basin ended about 1270-1250 Ma (Pajunen and Wennerström, 2010), and its geological history until the deglaciation and deposition of the interlobate glaciofluvial complex is unknown.

Detailed study of the depositional characteristics of interlobate glaciofluvial complexes, infilling a major bedrock depression, relies on geophysical methods such as ground penetrating radar (GPR) and the increasingly more costeffective (e.g., landstreamer) high-resolution seismic reflection method (HRSR). The ability to resolve structures at depth in saturated, $>100$-m-thick glacial sediments makes the HRSR method excellent compared to GPR, which has penetration depths limited to 20-40 meters depending on the antenna frequency and electrical conductivity of the materials. The HRSR method with landstreamer has been used during various hydrogeological studies of tunnel valley aquifers in Canada and the United States (Pugin et al., 2004; Ahmad et al., 2009; Pugin et al., 2009; Pugin et al., 2014a), and in esker characterization in Canada (Sharpe et al., 1992; Barnett et al., 1998; Pugin et al., 1999; Cummings and Russell, 2007; Pullan et al., 2007; Tremblay et al., 2010; Cummings et al., 2011), Finland (Maries et al., 2017; Brodic et al., 2018), and the European Alps (Burschil et al., 2018).

The Köyliö interlobate glaciofluvial complex hosts a substantial ground water reservoir, which has a high importance for the surrounding communities' water supply. The hydrogeological characteristics of the glaciofluvial sediments in the Köyliö area were earlier investigated during 2014 (Ahokangas and Mäkinen, 2014) in collaboration with the environmental authorities and neighboring communities to understand the depositional conditions of the glaciofluvial complex. However, the depth penetration of GPR (ca. $20 \mathrm{~m}$ ) and limited drillhole depths $(9-47 \mathrm{~m})$ were inadequate for the investigation of the deeper parts of the glaciofluvial complex.

The primary objective of the survey is to investigate the poorly known dimensions and tectonic characteristics of the Satakunta sandstone depression and related glacial stratigraphy to better characterize the composition of the glaciofluvial complex and its interlobate origin. The secondary objective is to determine the position of the possible high-conductivity, gravelly esker core and its connection with the other sediments that infill the sandstone depression. In addition, we explore the nature of the bedrock depression as a possible tunnel valley environment. We conducted a seismic survey with a newly developed digital-based landstreamer system (Brodic et al., 2015; Malehmir et al., 2016) during August 2014. This paper presents the first application of the landstreamer-based HRSR survey to characterize a sedimentary rock depression and infilling late-Quaternary interlobate glaciofluvial sediments in Finland.

\section{THE STUDY AREA}

\section{Bedrock characteristics and the tectonic development of the Satakunta sandstone basin}

The predominantly crystalline bedrock of southwestern Finland formed ca. 1900-1800 Ma during the Svecofennian orogeny. After the orogeny, marked tectonic movements and erosion related to isostatic balancing reactivated earlier fault structures, and new brittle structures formed (Pajunen and Wennerström, 2010). In the Köyliö area, the Svecofennian plutonic rocks consist mostly of granites, tonalities, granodiorites, and the supracrustal rocks of mica gneisses and schists (Veräjämäki, 1998). The most important tectonic movements after the Svecofennian orogeny are related to the rapakivi intrusion ca. $1650-1550 \mathrm{Ma}$, the formation of the Jothnian sedimentary basin at ca. 1400-1300 Ma, and the setting of the post-Jothnian olivine diabases $1270-1250 \mathrm{Ma}$ (e.g., Pajunen and Wennerström, 2010). The Svecofennian structures have influenced the setting of the rapakivi granites (Pajunen et al., 2008) and the development of the young brittle structures and partly determined their characteristics (Pajunen et al., 2001). Young tectonic events were concentrated mainly on the old weakness zones of bedrock (Elminen et al., 2008; Pajunen et al., 2008).

The Satakunta sandstone basin is located in a large northwest-southeast oriented graben ca. $70 \mathrm{~km}$ north of the city of Turku. The steep northwest-southeast oriented vertical faults partly border the graben (Heikkinen et al., 1998; Paulamäki and Paananen, 2001). The sandstone has a sharp contact to the porphyritic rapakivi granite and basement rocks (granodiorite) in the east (Veräjämäki, 1998) (Fig. 2). Pajunen and Wennerström (2010) interpreted the sandstone basin as an oblique transtensional structure with a polyphase kinematic history that caused complex fault structures and open folding in the sandstone layers. The sandstone is intruded by olivine diabases occurring as large mafic laccoliths (Elo and Pirttijärvi, 2010; Pajunen and Wennerström, 2010) and narrower diabase dykes. The stratified sandstone is fine- to coarsegrained, its bedding thickness varies from a few centimeters up to a meter (Veräjämäki, 1998), and it was deposited by poorly channeled braided streams in an alluvial environment (Kohonen et al., 1993; Pokki et al., 2013). The maximum thickness of the sandstone based on gravimetric data is ca. $1800 \mathrm{~m}$ (Elo, 1976). Based on the gravimetric studies (Elo et al., 1993), it is ca. 180-195 m thick between Lake Köyliönjärvi and Pyhäjärvi. Diabase dykes (40-60 m thick) occur within the sandstone west of Lake Pitkäjärvi (Kurimo et al., 1992). Quaternary deposits mostly cover the sandstone basin, and only some sandstone exposures exist outside the study area (cf. Pajunen and Wennerström, 2010). 


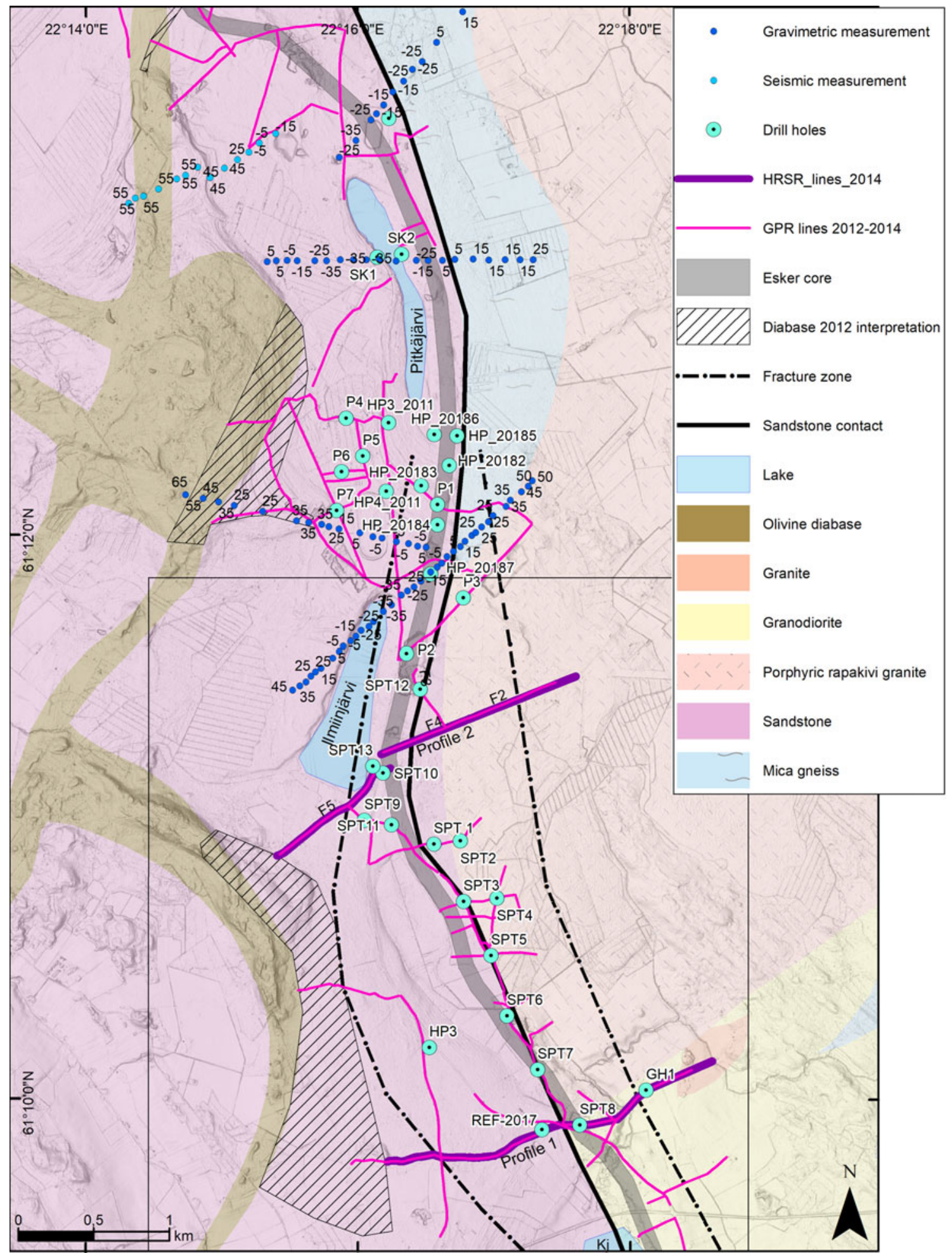

Figure 2. (color online) The Köyliö study area with lake bodies (Kj: Lake Köyliönjärvi), drill holes, gravimetric and refraction seismic bedrock elevation measurements (m asl), 2012-2014 ground penetrating radar (GPR) and landstreamer seismic profiles, the GPR-based estimations of the location of the esker core and diabase veins, sandstone contact, extent of the fracture zone (Palmu et. al., 1994), and bedrock lithology. Lake bodies () National Land Survey of Finland, ground water areas (@ Finnish Environment Institute, and bedrock ( ) Geological Survey of Finland.

\section{The deglaciation and timing of esker deposits}

The deglaciation of southwest Finland related to the decay of the Baltic Sea Ice Stream from the III Salpausselkä to the Gulf of Bothnia (Kleman et al., 1997; Boulton et al., 2001) (cf. Fig. 1). This ice stream divided into two sublobes in southwest Finland after the ice margin had retreated from the III 
Salpausselkä. The glaciofluvial complex running between Neittamonnummi and Lake Köyliönjärvi (cf. Fig. 2) is a part of the Pori-Koski esker chain formed in an interlobate position between two sublobes (Saarnisto and Salonen, 1995; Mäkinen, 2004). The smaller Loimaa lobe in the southeast extended between the Pori-Koski esker chain and the Tampere interlobate zone. The western sublobe was more active on the sandstone area and in deeper water than the eastern Loimaa sublobe located on the Svecofennian rocks and in shallower water. The north-south oriented De Geer moraines on the southwest side of the Pori-Koski esker chain indicate an abrupt change in the direction of the ice margin (cf. Tikkanen, 1981) (cf. Fig. 1). The deglaciation of southwest Finland occurred during early Holocene between 11,600 and 11,000 cal yr BP (Hughes et al., 2016; Stroeven, 2016). The formation of Köyliönjärvi-Säkylänharju-Virttaankangas glaciofluvial deposits are dated to ca. 11,160-11,060 cal yr BP (Mäkinen, 2004), based on Sauramo's (1929) recession lines following the major esker chain through the Loimaa lowlands. The study area was subaquatic during initial deglaciation, and the highest shoreline (Yoldia Sea) was at ca. $170 \mathrm{~m}$ asl in the area (Eronen and Haila, 1990). The proglacial water depth ranged from ca. $220 \mathrm{~m}$ in the depression to $120-130 \mathrm{~m}$ in the surrounding area.

\section{The characteristics of the sandstone depression and infilling sediments}

Gravimetric, magnetic and refraction seismic measurements (Kurimo et al., 1992; Palmu et al., 1994) indicate a fracture zone up to $1 \mathrm{~km}$ wide between Lakes Köyliönjärvi and Pitkäjärvi (see Fig. 2). The sandstone-basement rock contact is within this fracture zone. The bedrock surface on the western flank of the sandstone depression varies from 70 to $20 \mathrm{~m}$ asl. The deepest parts of the sandstone depression are between elevations of -30 to $-50 \mathrm{~m}$ asl. The deep drill hole (SK 2) (see Figs. 2, 4) completed east of Lake Pitkäjärvi intercepted 92-m-thick sediments above the sandstone within the fracture zone (Johansson and Taanila, 1975). The sediment cover is at its thinnest over the diabase (2-20 m; Lindroos et al., 1983), but it is commonly over $50 \mathrm{~m}$ and up to $90-100 \mathrm{~m}$ thick in the sandstone area.

The sandstone depression aligns obliquely with the ice flow directions of the Baltic Sea ice lobe in the deglacial phase (cf. Tikkanen, 1981). The large size of the Säkylänharju-Virttaankangas interlobate glaciofluvial complex (1-3 km wide and almost $22 \mathrm{~km}$ long) southeast of the Köyliö sandstone area, parts of which rise $70 \mathrm{~m}$ above the surrounding plains, is explained by the availability of easily erodible sandstone (Kaitanen and Ström, 1978). Sediments preceding esker core formation were imaged in an HRSR survey from the bedrock fracture beneath the SäkylänharjuVirttaankangas glaciofluvial complex ca. $20 \mathrm{~km}$ southeast of the Köyliö area (cf. Maries et al., 2017), implying that they may also exist in the Köyliö area.

The studied glaciofluvial complex emerges from the northwestern end of Lake Köyliönjärvi. The glaciofluvial ridge is most distinct between Lake Köyliönjärvi and Neittamonnummi, where its altitude is ca. 5-8 $\mathrm{m}$ above the surrounding areas. The ridge form disappears and the topography becomes flat in the Neittamonnummi area where the whole esker descends into the deep sandstone depression. Based on the sedimentology of the glaciofluvial sediments to the southeast of Lake Köyliönjärvi (Mäkinen, 2003a), the esker core of the glaciofluvial complex formed time-transgressively in a subglacial tunnel and was buried by repeated subaqueous fan sediments. Also, there the esker core follows the sandstone depression before it rises over the Svecofennian basement contact.

\section{METHODS AND MATERIALS}

The Köyliö study area was investigated using a combination of earlier GPR (2012-2014) data (Mäkinen and Ahokangas, 2012; Ahokangas and Mäkinen, 2014) and new HRSR data (2014), supported by the available reference drill holes. Several drillings were conducted in the study area between 2012 and 2018 (cf. Figs 2-4), including our new drill hole REF-2017, which drilled down to the sandstone bedrock to support the interpretation of the southern HRSR line. Additional information about bedrock depth was obtained from a private resident's geothermal heat well near seismic profile 1 (drill hole GH1) as well as two deep drill holes (SK1 and SK2) made in the 1970s (Johansson and Taanila, 1975). Destia Ltd and Suomen Pohjavesitekniikka Ltd made the drill holes with a heavy drill machine, including a 3-m bedrock confirmation when bedrock was reached. All drill holes were cored to obtain the lithology of the sediments, but no sampling was performed. Ground water pipes were installed in most of the drill holes (excluding REF-2017, SK1, SK2, and GH1) for the observations of the Centre for Economic Development, Transport and the Environment. Most of the drill holes made during the hydrogeological investigations do not reach bedrock and are restricted to $9-47 \mathrm{~m}$ in depth due to cost and pumping well depth limitations (see Fig. 4). The Pitkäjärvi deep drill holes (SK1 and SK2) reach the sandstone at a depth of 91-92 m, and REF-2017 reaches sandstone at $60 \mathrm{~m}$ within the depression. Drill holes SPT2, SPT4, and GH1 reach the Svecofennian basement bedrock on the eastern side of the depression.

The Geological Survey of Finland (GTK) conducted three GPR reconnaissance surveys with $100 \mathrm{MHz}$ antennae in 2012-2014, yielding a total of $40 \mathrm{~km}$ of GPR lines. The dielectricity value used was 6 , and measurement time was $400 \mathrm{~ns}$. The data were processed with background removal calculated from data, high and low pass filtering, and slight signal enhancement. No further processing was applied to the data. The radar profiles were plotted as .tiff images with a length scale of $10 \mathrm{~m} / \mathrm{cm}$. The 2014 GPR lines were acquired for ground water investigations between Lake Köyliönjärvi and Lake Ilmiinjärvi (cf. Fig. 3). These lines provided information on the ground water level, the uppermost $2-15 \mathrm{~m}$ of sedimentary structures, and the depth of the diabase bedrock in the west (Mäkinen and 


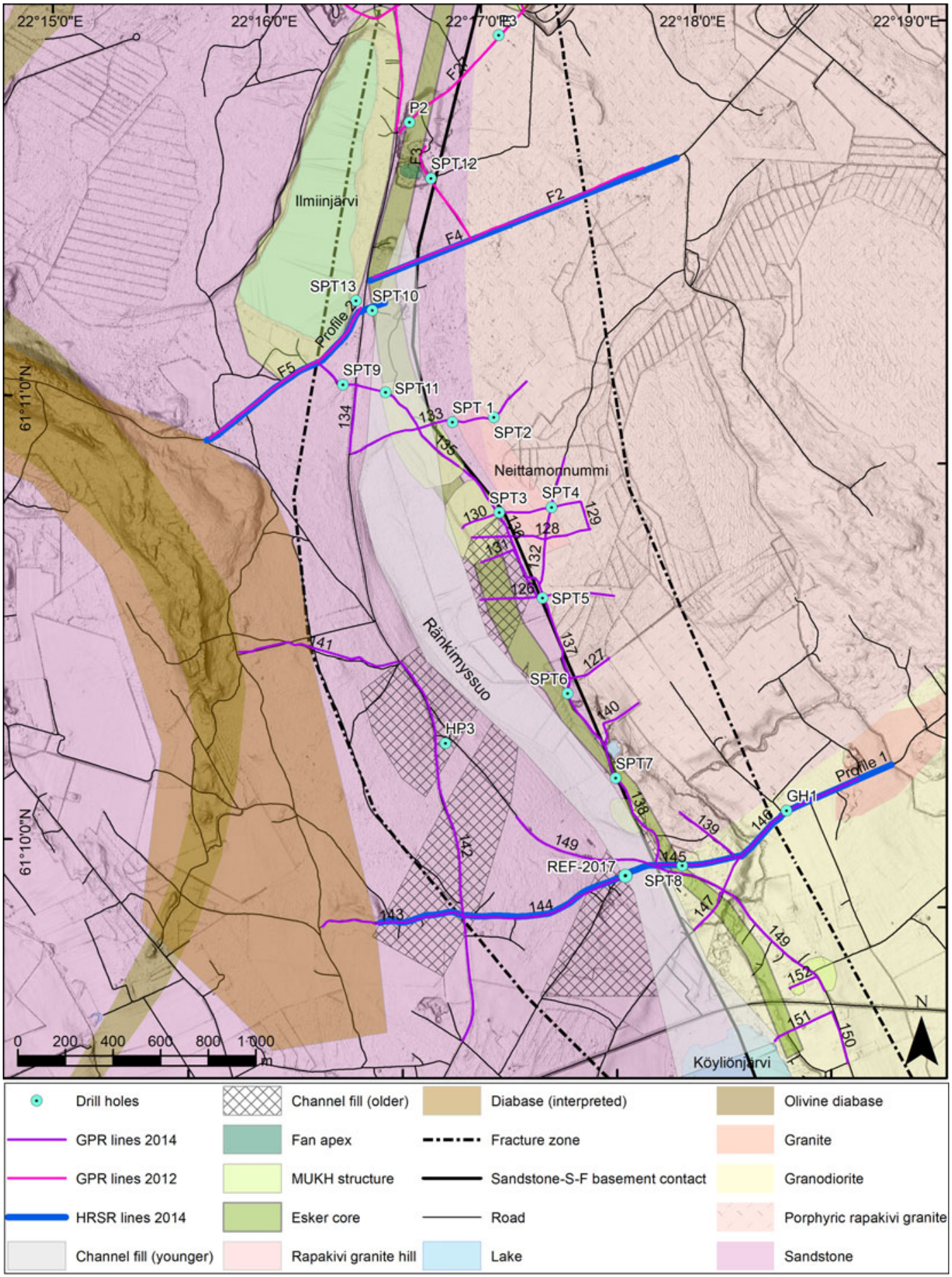

Figure 3. (color online) The drill holes, 2012 and 2014 ground penetrating radar (GPR) survey lines, 2014 high-resolution seismic reflection (HRSR) lines (profiles 1 and 2), interpreted esker elements, and diabase and rapakivi granite hill (Ahokangas and Mäkinen, 2014), roads, the position of the sandstone contact, and bedrock lithology. () Geological Survey of Finland. MUKH is morphologically undetectable kettle hole.

Ahokangas, 2012; Ahokangas and Mäkinen, 2014). The presence of fine-grained beds and clay decreased the penetration depth of the GPR in the Neittamonnummi area (see Fig. 4, drill holes SPT4-SPT5).

The seismic survey consisted of two seismic profiles (profile 1 and 2, see Fig. 3), each over $2 \mathrm{~km}$ long acquired mainly along the available gravel roads in the forest. The ground water table is at a depth of $1-13 \mathrm{~m}$ along seismic profile 1 and 3-8 $\mathrm{m}$ along seismic profile 2, placing most of the esker below the water table. We acquired the data with a newly developed broadband seismic landstreamer (Brodic et. al, 2015) designed for high-resolution near-surface applications. We used the landstreamer, consisting of four segments, each containing 20 microelectromechanical 


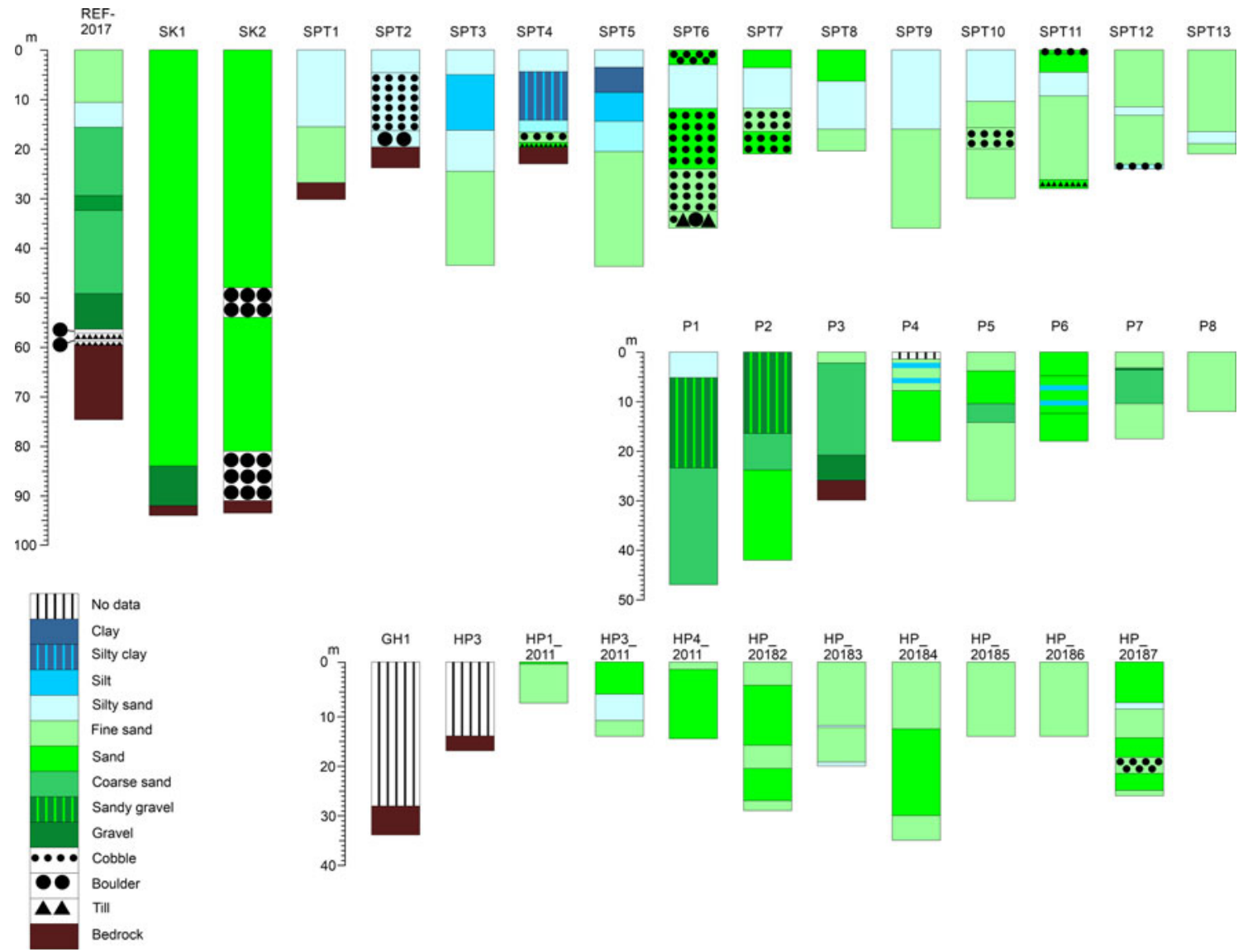

Figure 4. (color online) The lithology of drill holes in the Köyliö study area (cf. Figs 2 and 3 for locations).

broadband sensors (Fig. 5a), resulting in a total spread $200 \mathrm{~m}$ long for fast and efficient data acquisition. Although threecomponent data were recorded, we have used only vertical component data for this study. The data acquisition of 5 $\mathrm{km}$ of HRSR and refraction data (2-4 $\mathrm{m}$ receiver and shot spacing) took 5 days. We generated seismic energy using a $500-\mathrm{kg}$ drop-hammer mounted on a Bobcat vehicle. To achieve greater length coverage and properly record refracted arrivals from the bedrock, 50 wireless recorders connected to $10 \mathrm{~Hz}$ geophones (see Fig. 5b) were spaced along each profile (10-20 $\mathrm{m}$ apart) in two or three stages (roll-along), covering the entire length of each profile. The maximum offset obtained this way was about $1000 \mathrm{~m}$. Since the survey relied on the available roads, the wireless recorders also had the advantage of providing some data near crossing roads or bridges.
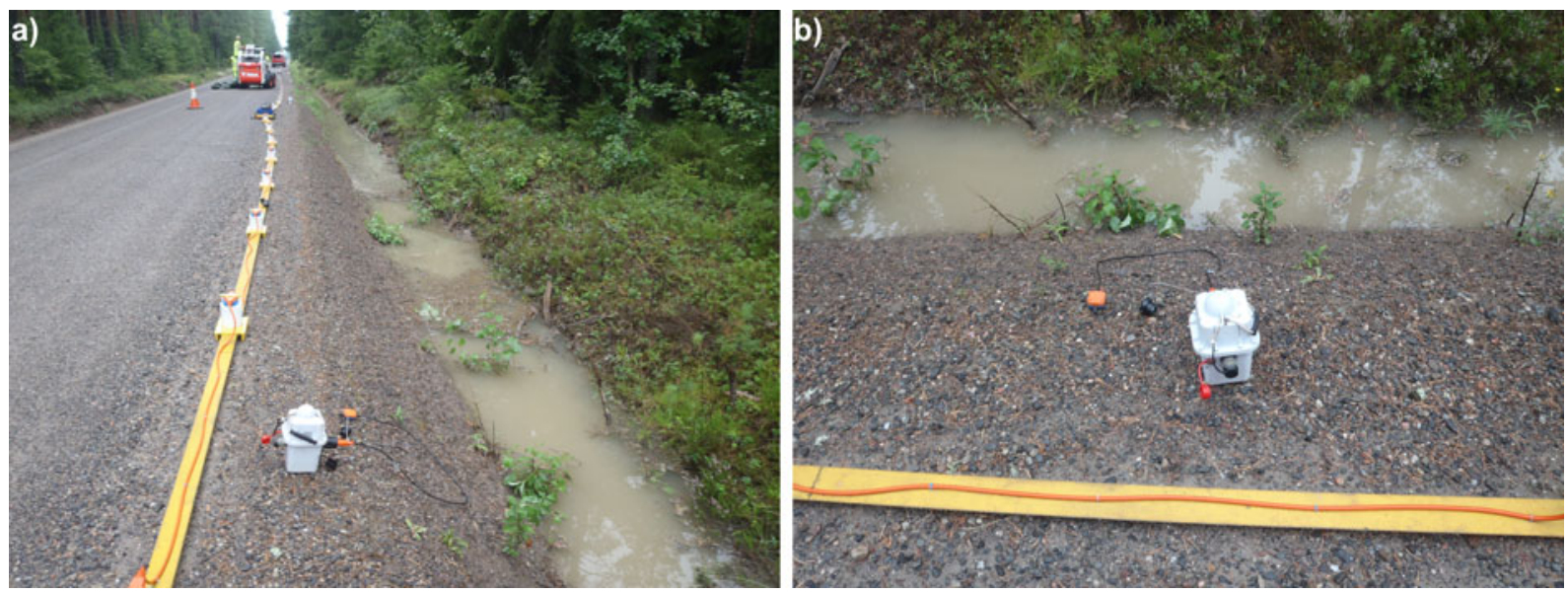

Figure 5. (color online) (a) The landstreamer with attached microelectromechanical broadband sensors placed on the gravelly road along profile 2. (b) The wireless $10 \mathrm{~Hz}$ geophone placed adjacent to the landstreamer. 
We picked first breaks of each shot record and used a 3D turning-ray travel time tomographic inversion algorithm (Tryggvason et al., 2002) to make a near-surface velocity model fitting to the observed travel times. Root mean square errors of the final model were 2 and $2.3 \mathrm{~ms}$ for profiles 1 and 2 , respectively. Reflection data processing followed a conventional processing flow (Malehmir et al., 2013b; Maries et al., 2017) focused on prestack signal enhancements and including common midpoint stacking. The most time-consuming part was obtaining a proper normal move-out velocity to account for the steep velocity gradient with the depth and the dipping nature of the bedrock. The seismic reflection sections were migrated and converted from time to depth using a velocity of $1400 \mathrm{~m} / \mathrm{s}$ for profile 1 and $1300 \mathrm{~m} / \mathrm{s}$ for profile 2. The uppermost 10-20 $\mathrm{m}$ have few reflections in the seismic profiles. As such, the existing GPR lines and the previous sedimentological interpretations based on them (Mäkinen and Ahokangas, 2012; Ahokangas and Mäkinen, 2014), as well as drill hole data, were used to supplement the HRSR profiles and interpretations for the uppermost $20 \mathrm{~m}$ near the land surface (Ahokangas and Mäkinen, 2014) (cf. Fig. 3) where the seismic profiles had poor quality due to low fold in near offsets.

\section{RESULTS AND INTERPRETATION}

\section{The interpretation of the seismic data in the Köyliö study area}

The high quality of the HRSR data allows both the bedrock and esker sediment characteristics in the Köyliö area to be interpreted. The deepest interpretable reflections extend to the depth of $-150 \mathrm{~m}$ asl. The refraction tomography profile with velocities (Fig. 6) and drill holes allows the separation of infilling esker sediments and the bedrock surface within the sandstone depression. The bedrock structural features had similarities in both seismic profiles, and therefore the results are presented only for profile 2 (cf. Fig. 7). The position of the sandstone contact was interpreted with refraction tomography and the seismic reflection profiles, as well as with the drill hole information and previous work by Palmu and colleagues (1994). The bedrock elevation was interpreted from a combination of the first travel time tomography and reflection seismic profiles. We used the velocity for sandstone $(3000-4000 \mathrm{~m} / \mathrm{s})$ for the outlining bedrock elevation in the southwest end of the profiles (see Fig. 6).

\section{The implications of the Köyliö drill hole data}

The drill holes in Neittamonnummi and the surrounding areas aided in the bedrock surface interpretations of the seismic sections (cf. Fig. 4). Only drill holes GH1, P3, SPT1, SPT2, SPT4, REF-2017, SK1, and SK2 intercepted the bedrock at 16.45 to $-42 \mathrm{~m}$ asl. The bedrock surface in the rapakivi granite area of Neittamonnummi is in the depth of 27-35 $\mathrm{m}$ asl (SPT1, SPT2, and SPT4). The bedrock elevation is on average at $15-35 \mathrm{~m}$ asl outside the sandstone depression (drill holes HP3, GH1) (cf. Fig. 2).

The other drill holes (19.7-47 m deep) reached mostly fine-grained to sandy sediments (clay-silt, fine sand, and sand), supporting the presence of the sandstone depression. Coarse sand and bouldery sand sediments occur in drill holes SPT6 and SPT7 between the seismic profiles and in P1 and P2 north of profile 2 as well as in the deep drill holes REF-2017, SK1, and SK2. The new 75-m-deep reference drill hole (REF-2017) made next to profile 1 on the southwest flank of the sandstone depression reveals coarse sand, gravel with cobbles, and boulders on top of sandstone. Drill hole SK1 revealed $80 \mathrm{~m}$ of sand and $8 \mathrm{~m}$ of gravel, and SK2 revealed alternating sand and boulder beds on top of the sandstone. We interpret these to signify the presence of the esker core within the sandstone depression.

\section{Bedrock characteristics and the structure of the sandstone depression}

Seismic profiles 1 and 2 provide a delineation of the sandstone depression and the bedrock surface with reasonable accuracy. No clear high-velocity (e.g., >5000 m/s) boundary was reached in the depression zone tomography sections because of a combination of thick esker sediments (up to $100 \mathrm{~m}$ ) and sandstone at the bottom of the depression. Coarse-grained sandstone and the overlying thick sediments also affected the general quality of the tomography profiles. The low seismic velocities $(3000-4000 \mathrm{~m} / \mathrm{s})$ originate from the sandstone and fractured bedrock near the contact of granodiorite and rapakivi granite along the northeast part of profile 1 (see Fig. 6a). These velocities agree with previous refraction seismic soundings northwest of Lake Pitkäjärvi, approximately $5 \mathrm{~km}$ north of the study area (cf. Fig. 2) (Geological Survey of Finland, 1973). It provided velocities of 3500$3800 \mathrm{~m} / \mathrm{s}$ for the sandstone and $3350-4500 \mathrm{~m} / \mathrm{s}$ for the diabase dykes (Lindroos et al., 1983).

Based on the seismic profiles, the sandstone depression is approximately 800-850 m wide and extends down to a depth of ca. $100 \mathrm{~m}$ (see Figs. 6a and 6b). This calculated depth correlates well with the 92-m-deep Pitkäjärvi drill hole SK1 (Johansson and Taanila, 1975) and with depths provided by the earlier seismic and gravity profiles (Palmu et al., 1994). However, the previous interpretation (Palmu et al., 1994) of the width of the fracture zone is $400-600 \mathrm{~m}$ too wide in the east compared to the seismic data. The difference is more apparent along seismic profile 2 (see Fig. 6b). An abrupt drop in the bedrock surface (profile 1: 1700-1800 m, profile 2: 1050-1100 m) is observed in both the tomography models (see Fig. 6) and the reflection seismic profiles (Figs. 8 and 9). This steep drop is interpreted as the position of the sandstone contact. The contact appears to be about $500 \mathrm{~m}$ farther east in profile 1 (distance 1700 $1800 \mathrm{~m}$ ) (see Figs. 6a and 9) and about 350-400 m farther west in profile 2 (distance 1000-1100 m) (see Figs. 6b and 9).

A strong and continuous reflection is observed in both seismic profiles 1 and 2 (see red solid line, Figs $8 \mathrm{~b}$ and $9 \mathrm{~b}$ ). It is 

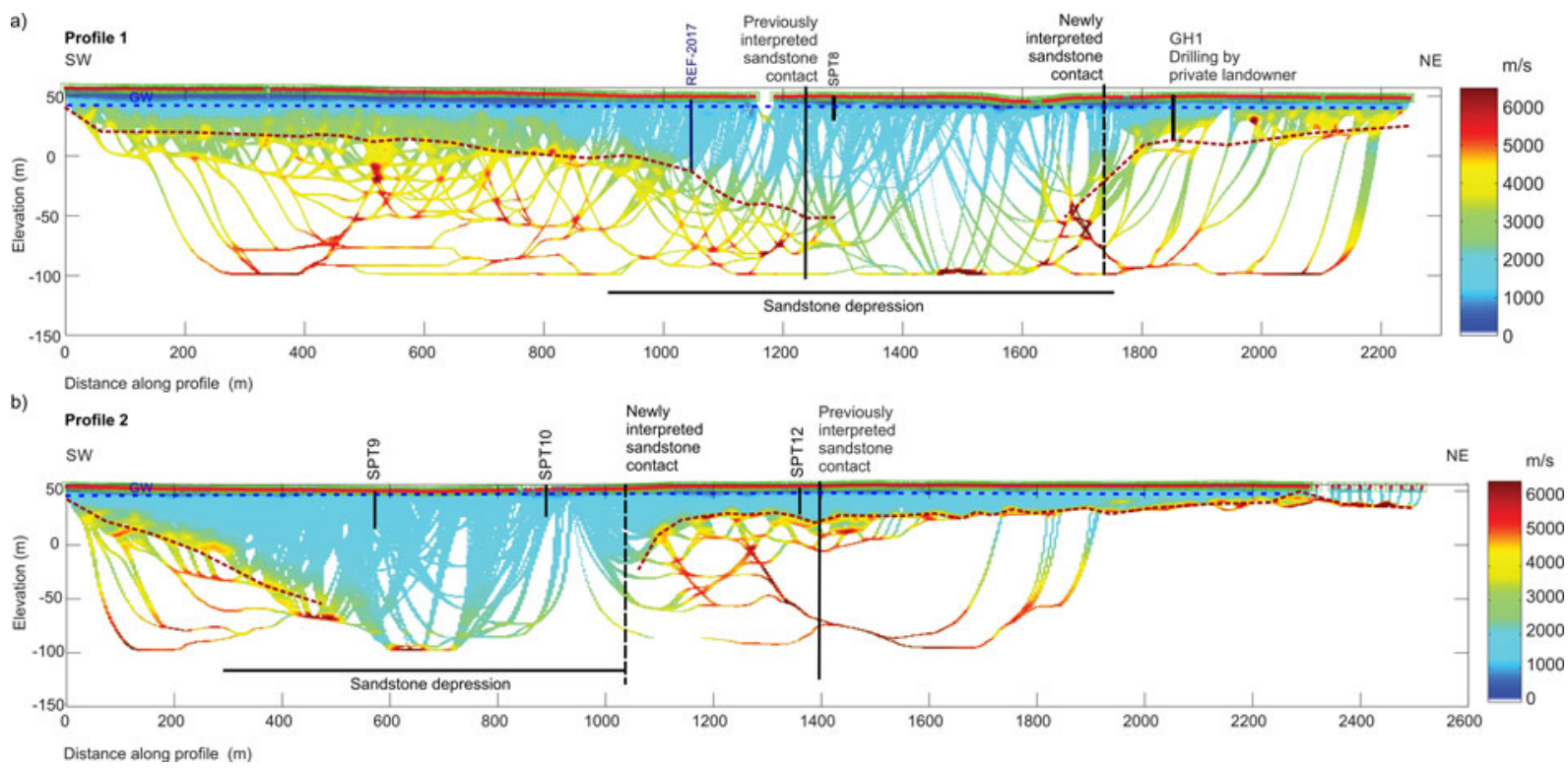

Figure 6. The seismic refraction tomography sections for profiles 1 and 2 . The reference drill holes, water table (blue dashed line), bedrock level (red dashed line), position of previously interpreted and newly interpreted sandstone contact, and the newly interpreted extent of the sandstone depression are annotated on the profiles. The previously interpreted sandstone contact is based on pre-Quaternary bedrock mapping. (a) Profile 1 shows low velocities $(<4000 \mathrm{~m} / \mathrm{s})$ on the interpreted bedrock level. (b) Profile 2 shows higher velocities ( $>4000 \mathrm{~m} / \mathrm{s}$ and shows a more distinct bedrock surface in the northeast part of the profile.

the strongest in parts of profile 1 (distance $950-1250 \mathrm{~m}$ ) and profile 2 (200-550 m, 1200-2100 m). The level of this reflection varies along profile 1 between 20 and $-40 \mathrm{~m}$ asl (see Fig. 8b). Along profile 2, it deepens from $20 \mathrm{~m}$ asl down to $-70 \mathrm{~m}$ asl. A steep contact at a $1050-\mathrm{m}$ distance interrupts the reflection, and then it rises to $0-20 \mathrm{~m}$ asl (see Fig. 9b). There is a small 200-m-wide and 10-m-deep concave drop in the reflector (distance $1500 \mathrm{~m}$ ) in profile 1, indicated also by the collapsed sediments above (see pink shaded area, Fig. 8b). We interpret the continuous reflection to be associated with bedrock surface, which is supported by the two reference drill holes (GH-1, REF-2017) along profile 1. Reference drill hole REF-2017 reached compact and solid sandstone without indications of fracturing or weathering (Murto, S., personal communication, 2017). The small drop (profile 1 at $1500 \mathrm{~m}$ ) in the bedrock elevation is interpreted to coincide with a vertical fault. The accuracy of the bedrock elevation between the 2017 reference drill hole (REF-2017) and the interpreted bedrock reflections in profile 1 is $2-3 \mathrm{~m}$. The bedrock surface interpretation has some uncertainties in the deepest part of the sandstone depression. This is due to a thick sediment cover overlying the fractured bedrock surface (cf. Figs. 8 and 9). Therefore, the accuracy of the interpretation may fall to $5-10 \mathrm{~m}$ in the deepest part of the depression. Some strong, nearly horizontal reflections are present within the bedrock at -25 to $-50 \mathrm{~m}$ asl in profile 1 (see lilac dashed lines, Fig. $8 \mathrm{~b}$ ). We interpret these as horizontal diabase laccoliths.

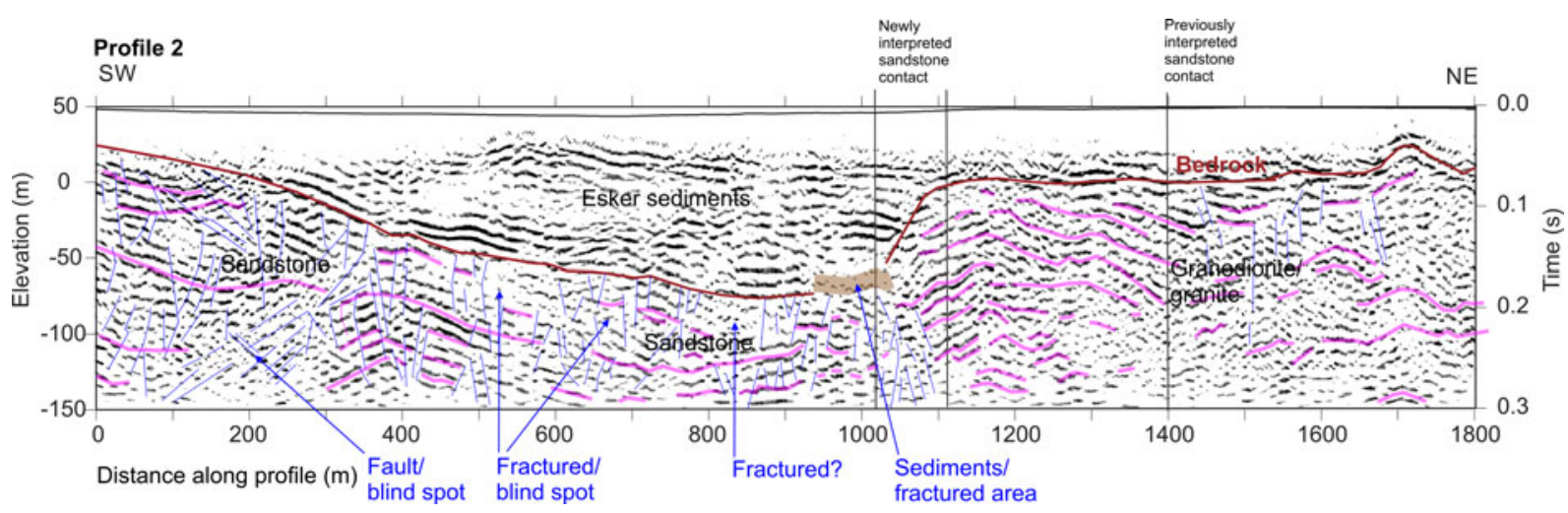

Figure 7. The tectonic interpretation of the bedrock in seismic profile 2 showing the interpreted bedrock surface (dark red solid line), brittle faults, fracture zones and intense jointing (blue lines), bending of the sandstone bedding (pink lines), and the sediments or fractured area (brown shaded area). (For interpretation of the references to color in this figure legend, the reader is referred to the web version of this article.) 

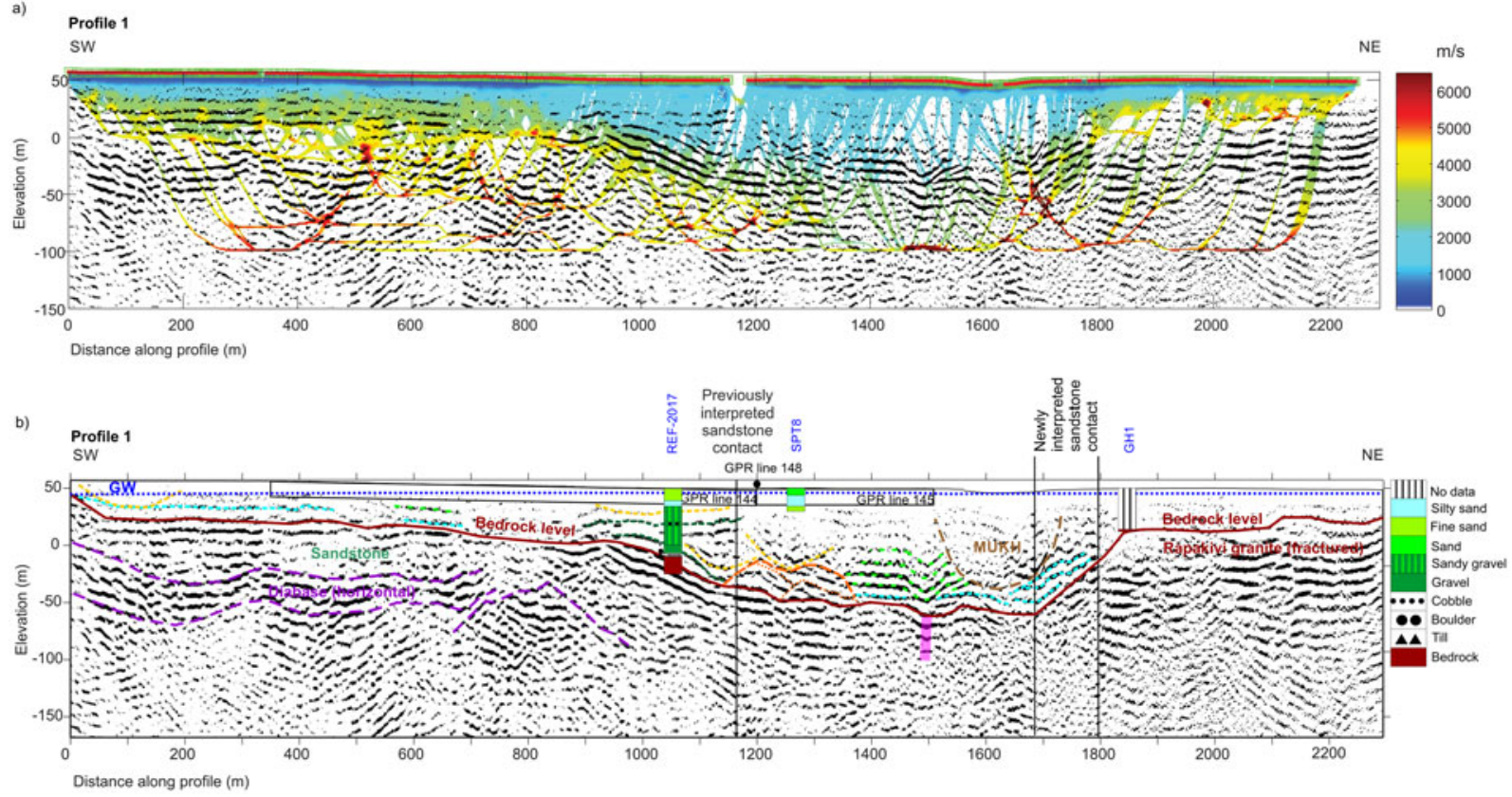

Figure 8. (a) Profile 1 first break travel time tomography results projected onto the reflection seismic profile. Low velocities $(<2000 \mathrm{~m} / \mathrm{s})$ indicate the infill of the sandstone depression. (b) Interpretation of the seismic profile 1 including bedrock elevation (red solid line), horizontal diabase (lilac dashed lines), positions of the former and newly interpreted sandstone contact (black solid vertical lines), a fault (pink shaded area), the arched esker core (orange dashed line), till or gravel sediments (turquoise dashed lines), gravel beds (dark green dashed lines), fan lobe channels (yellow dashed lines), fine-grained to sandy sediments (light green dashed lines), and a morphologically undetectable kettle hole (MUKH) structure (brown dashed line). The 2017 reference drilling is at a distance of $1050 \mathrm{~m}$. The positions of ground penetrating radar (GPR) lines 144 and 145 are parallel, and GPR line 148 is diagonal to the seismic profile (black dot for interception point).

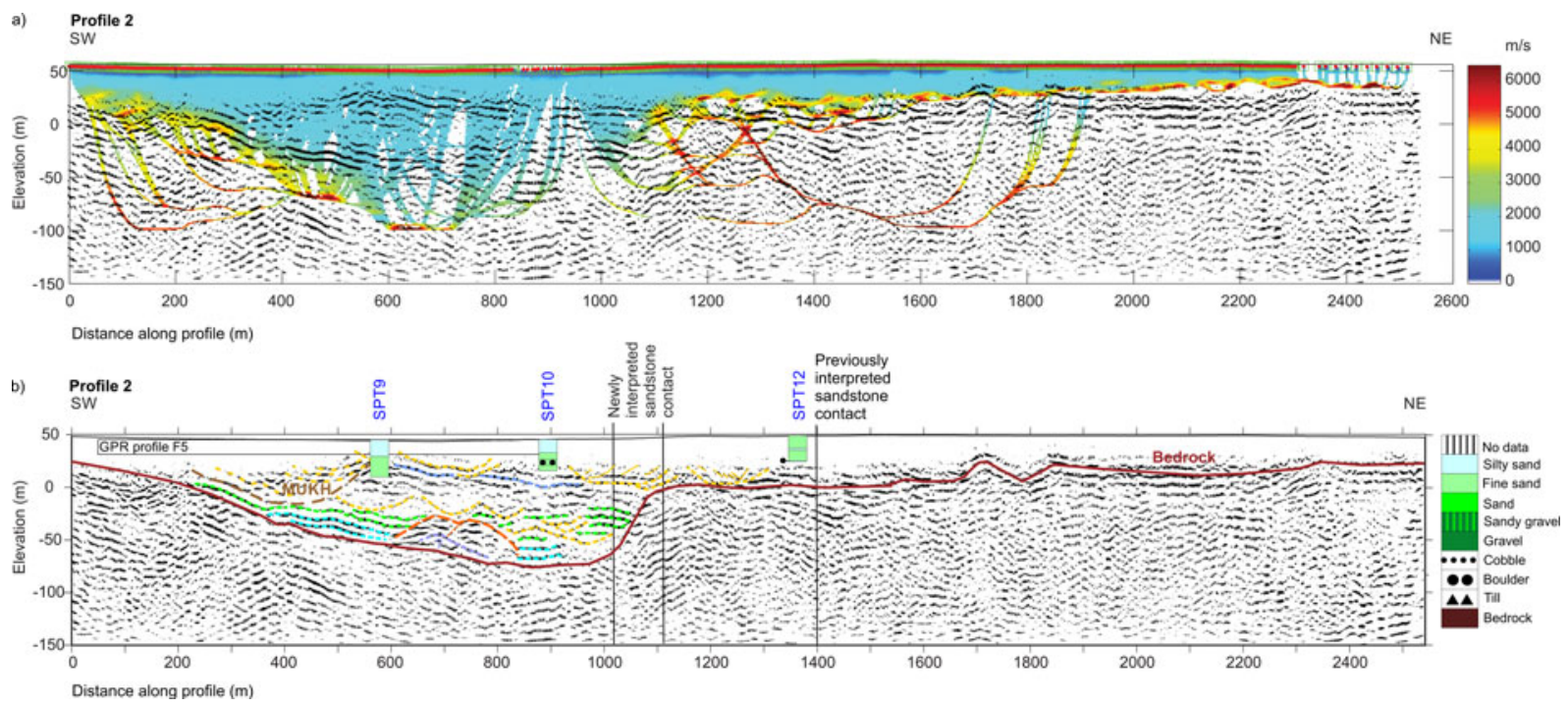

Figure 9. (a) Profile 2 first break travel time tomography results projected onto the reflection seismic profile. (b) Seismic profile 2 with interpreted positions of the former and new interpreted sandstone contact (black solid vertical lines) and esker elements. The horizontal beds (turquoise and light green dashed lines) on top of the gently sloping bedrock are flanking the esker core (orange dashed line). A remnant of the esker core (pastel blue dashed line) underlies the esker core. The coarse-grained esker core (orange dashed line) is overlain by subaqueous fan channel fills (yellow dashed lines). A morphologically undetectable kettle hole (MUKH) structure is shown with brown dashed line. The uppermost fine-grained esker sediments (dashed dark blue line) in the upper part of the profile are supported by the drill holes (SPT9, SPT10, and SPT12). 
Figure 7 shows a tectonostratigraphic interpretation of seismic profile 2 . The reflections are cut by a systematic array of breaks forming a structure corresponding to that seen on the sandstone outcrops nearby in Kiparoja, Eura (Pajunen and Wennerström, 2010). These breaks (see thin blue lines, Fig. 7) represent brittle faults, fracture zones, and intense jointing. We interpret the continuous and high to moderate amplitude 100-300-m-long convex reflections (see pink lines, Fig. 7) as an open fold structure. Pajunen and Wennerström (2010) described similar open folding on the outcrop from the eastern end of Leistilänjärvi, Nakkila. The origin of the fractured area (see brown shaded area, Fig. 7) interrupting the bedrock surface close to the Svecofennian-sandstone border (distance $1000 \mathrm{~m}$, depth ca. $-50 \mathrm{~m}$ asl) is not known. It could be a collapsed structure similar to that shown in the Vampula mine, where sediments (Pokki, J., personal communication 2018) exist as strongly brecciated fragments in a clayey fault rock (gouge).

\section{Sedimentary fill of the sandstone depression}

\section{The sediments overlying the bedrock}

A 10-15-m-thick layer occurs above the bedrock surface with seismic tomography velocities of $2000-3000 \mathrm{~m} / \mathrm{s}$ (distances 0-700 m, 900-1100 m, and 1400-1850 m) in profile 1 (see Fig. 8a) and in profile 2 (distances $350-500 \mathrm{~m}$ and $830-930 \mathrm{~m}$ ) (see Fig. 9a). The layer corresponds with nearly horizontal and slightly inclined strong reflections on top of the interpreted bedrock surface in seismic profiles (see turquoise lines, Figs. $8 \mathrm{~b}$ and $9 \mathrm{~b}$ ). The stacked arched-shaped reflections interrupt these reflections. The drill hole REF-2017 (at $1050 \mathrm{~m}$ ) along profile 1 intercepted a $3.8-\mathrm{m}$ bed of bouldery $(0.8 \mathrm{~m}$ in diameter) diamicton (at a depth of 56.2-60 m) overlying the bedrock on the southwest side of the arched reflections (see Figs. 4 and 8b). A 7.2-m-thick gravel bed overlies a $0.8-\mathrm{m}$ diameter boulder on top of the diamicton bed. Common seismic velocities for sand and gravel are $400-2300 \mathrm{~m} / \mathrm{s}, 1500-2700 \mathrm{~m} /$ s for glacial moraine (Reynolds, 2011), and ca. $2000 \mathrm{~m} / \mathrm{s}$ for tills (Malehmir et al., 2013a; Salas-Romero et al., 2015). The velocity ranges reported in the literature are overlapping, and thus drill-hole observations are needed for confident interpretation of reflections in addition to tomographic model. In the Köyliö profile 1, the 10-15-m-thick layer seen in the seismic data could be interpreted to contain till and water-saturated gravel based on observations in drill hole REF-2017. The till bed on top of the solid bedrock produces a strong reflection package similar to that observed by previous workers in an esker sediment-filled bedrock fracture zone at the Virttaankangas area (Pugin et al., 2014b; Maries et al., 2017). However, no distinct reflection originated from the bouldery till on the southwest flank in profile 1.

The interpretation of the layers immediately overlying the bedrock and flanking the arched features (see turquoise lines, Figs. $8 \mathrm{~b}$ and $9 \mathrm{~b}$ ) in the sandstone depression is challenging. The margins of the arched feature are weak on both seismic profiles, and the arched reflections are quite similar in strength compared to the surroundings. The definition of the margins of the arched feature is difficult, leading to uncertainty in the interpretations.

The esker elements (esker core, subaqueous fan lobes, MUKH structures, and distal esker sediments)

The low-velocity sediments (1000-2000 m/s) with slightly undulating horizontal and concave moderate- to highamplitude reflections (see Figs. 8b and 9b) fill most of the sandstone depression. Their velocities correspond well with the refraction seismic sounding velocities from Koomankangas $5 \mathrm{~km}$ north of the study area with velocities of $300-1000 \mathrm{~m} / \mathrm{s}$ for unsaturated and $1380-1590 \mathrm{~m} / \mathrm{s}$ for saturated sediments (Lindroos et al., 1983). The ground water table is at ca. $45 \mathrm{~m}$ asl (drill hole SPT8) in profile 1 and $47 \mathrm{~m}$ asl in profile 2 (drill holes SPT9 and SPT10) (cf. Figs. 8b and 9b). The low-velocity zone of $<1000 \mathrm{~m} / \mathrm{s}$ is mostly above the water table and corresponds with the unsaturated silty to fine sand and sand sediments near the surface. The low-velocity sediments $(<2000 \mathrm{~m} / \mathrm{s})$ filling most of the sandstone depression are interpreted to represent the glaciofluvial complex.

Some indications of the position of the possible coarsegrained esker core are seen on the 2014 GPR lines 127, 128,130 , and 133 in the Neittamonnummi area, as well as on lines 145,147 , and 148 near seismic profile 1 in the form of arched architecture of the sediments. The top part of the esker ridge has an arched shape with few internal reflections on GPR profile 148 (Fig. 10a). In seismic data, a 30-m-high and 200-m-wide stacked arch-shaped feature with convex reflections (profile 1: -10 to $-45 \mathrm{~m}$ asl, 1150 $1400 \mathrm{~m}$, profile $2:-40$ to $-70 \mathrm{~m}$ asl, $600-850 \mathrm{~m}$ ) interrupts the interpreted till bed on top of the bedrock (see long orange dashed line, Figs. $8 \mathrm{~b}$ and $9 \mathrm{~b}$ ). The package is located $500 \mathrm{~m}$ southwest of the steep bedrock elevation drop (the new interpretation of sandstone contact position) in profile 1 . The stacked feature appears to consist of two arch-shaped parts (see short orange dashed lines, Figs. 8b and 9b). The stacked arched features are interpreted as the esker core based on the convex reflection packages, arched geometry, and dimensions typical to esker cores (100-200 m wide, $20-30 \mathrm{~m}$ in height) (Shreve, 1985; Pugin et al., 2009; Maries et al., 2017). Moreover, the core consists of two parts in the Vampula pit ca. $16 \mathrm{~km}$ southeast of the study area (Mäkinen, 2003b). The gravel-rich sediments found in the REF-2017 reference drill hole, together with the 2014 GPR profiles 145 and 148 (cf. Fig. 10a), suggest the position of the esker core on the southwest flank of the sandstone depression in profile 1 . Seismic profile 2 is slightly diagonal to the esker core, which makes the core appear slightly larger in the profile. The ca. $40-50 \mathrm{~m}$ thickness of the esker core is explained by overlapping proximal fan sediments (Mäkinen, 2003a). The GPR-based esker core position corresponds well with the interpretation of the esker core position from the seismic data.

A continuous reflection $(0 \mathrm{~m}$ asl at $950-1170 \mathrm{~m})$ immediately above the till bed occurs only on the southwest of the 

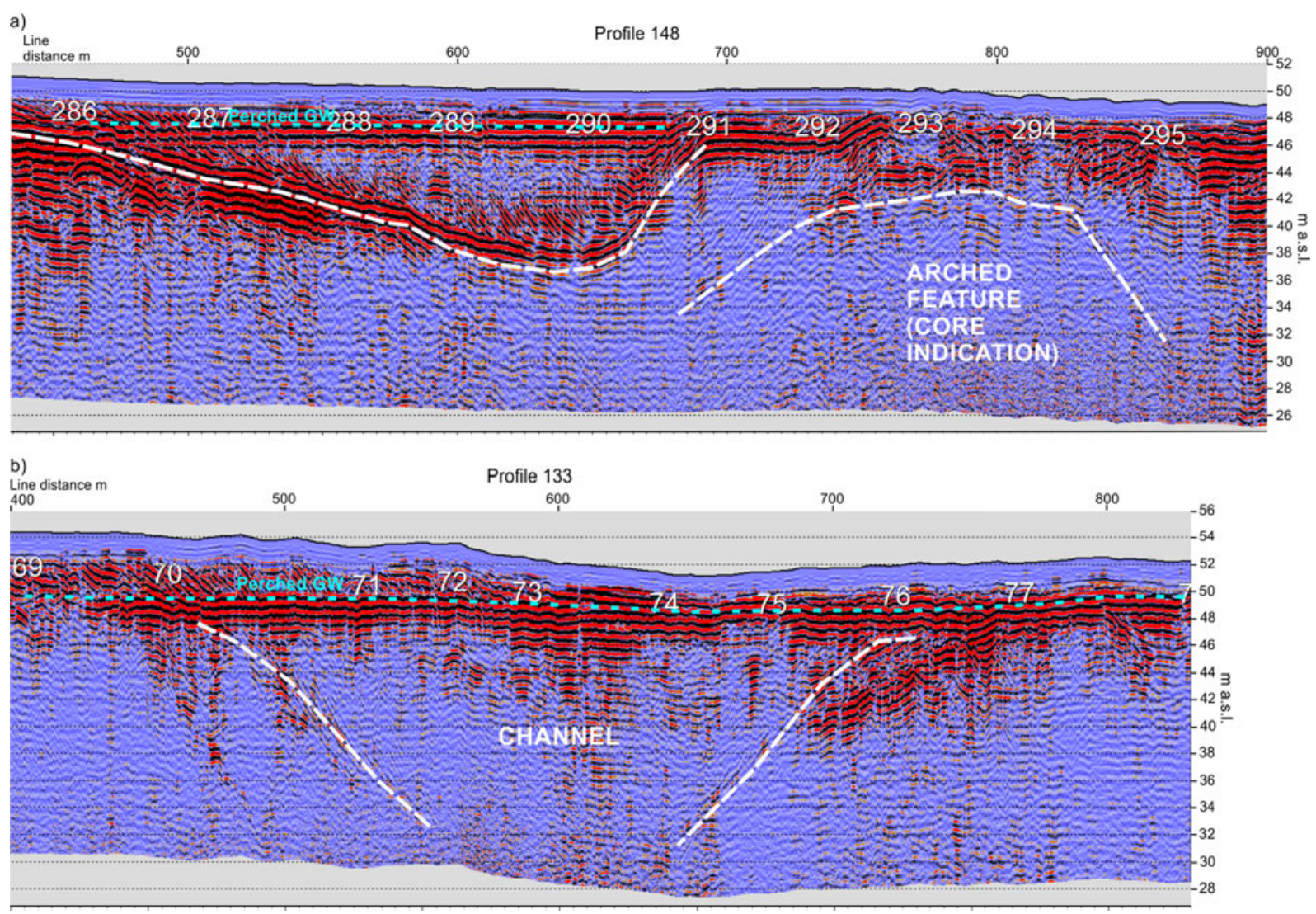

Figure 10. (color online) (a) The southeastern end of the Ränkimyssuo meltwater channel and the cupola-shaped indication of the esker core in ground penetrating radar (GPR) profile 148 crosscutting seismic profile 1. (b) The major meltwater channel in the area of the Ränkimyssuo peat bog revealed in GPR profile 133 near seismic profile 2.

esker core in profile 1. This reflection corresponds with a 7.2-m-thick gravel layer at 0.7 to $-6.5 \mathrm{~m}$ asl in REF-2017 (see dark green dashed line, Fig. 8b). This gravel bed is interpreted as representing coarser subaqueous outwash fan sediments on the southwest flank of the sandstone depression. It is plausible that the diamicton bed found on the bottom of the depression of profile 1 was eroded by the meltwater activity related to subaqueous outwash fan sediment deposition. The presence of this gravel layer in profile 2 could not be confirmed due to a lack of reference drilling. On the northeast side of the esker core in profile 1 , undulating nearly horizontal reflections ( -5 to $-45 \mathrm{~m}$ asl at $1400-1550 \mathrm{~m}$ ) end abruptly on the esker core and drape a fault ( $-60 \mathrm{~m}$ asl, $1500 \mathrm{~m}$ ) (see light green dashed lines, Fig. 8b). In profile 2, medium- to highamplitude, slightly undulating horizontal reflections are on both sides of the esker core (distance 300-600 m, 0 to $-20 \mathrm{~m}$ asl and distance $950-1050 \mathrm{~m},-20$ to $-40 \mathrm{~m}$ asl) (see light green dashed lines, Fig. 9b). Trough-shaped features truncate the reflections on the northeast side of the esker core in profile 2. We interpret these undulating horizontal reflections as the distal sandy subaqueous esker sediments. The sediments drape the fault symmetrically on profile 1 and do not have any indications of faulting or deformation, ruling out an MUKH structure interpretation. A discontinuous horizontal reflection (20 $\mathrm{m}$ asl at $900-1185 \mathrm{~m}$ ) found near the land surface in the southwest side of profile 1 corresponds with a cobble-rich layer encountered at $17.5-20.5 \mathrm{~m}$ asl in REF-2017 (see Fig. 8b). This reflection is interpreted as representing a stronger meltwater flow phase during the deposition of the fan sediments.

Several trough-shaped features $150-300 \mathrm{~m}$ in width and $20-30 \mathrm{~m}$ in depth are found on top and lateral to the esker core and near the land surface (see yellow dashed lines, Figs. 8b, 9b). These features are similar to overlapping, successive fan lobes described from the Virttaankangas glaciofluvial complex by Artimo and colleagues (2010) and Maries and colleagues (2017). We identified them based on the concave-shape of their bottom. Some may have finergrained beds beneath them (see blue dashed line, Figure 9b). Their fill contains weak and discontinuous reflections on top of the esker core and near the land surface in profiles 1 and 2 (see Figs. 8b, 9b). We interpret trough-shaped features as subaqueous fan channel fills (Miall, 1985), which are clear in GPR profiles. They show distinct margins, probably due to the presence of fine-grained (silty to fine sand) material beds at the bottom and on the sides. The interpreted wide and shallow trough-shaped feature (distance 900-1100 m) in profile 2 represents the bottom of the major Ränkimyssuo channel (200-250 m wide, 10-20 m deep) identified in GPR profiles 133 and 135 near profile 2 
and in GPR profiles 144, 145, and 148 near profile 1 (see Figs. 3 and 10b). Drill hole SPT11 intercepts the western flank of the channel and consists of fine sand. We cannot confirm the continuation of the channel between seismic profiles 1 and 2 due to the lack of GPR lines across the Ränkimyssuo peat bog (cf. Fig. 3). However, the other GPR lines around the peat bog do not show indications of the channel turning to the southwest-south or northeast.

A major 300-m-wide and 70-m-deep trough-shaped feature in seismic profile $2(-15$ to $20 \mathrm{~m}$ asl at $210-580 \mathrm{~m})$ is interpreted as an MUKH (see brown dashed line, Fig. 9b). Previously, this feature was interpreted as a major MUKH (cf. Mäkinen, 2003b; Artimo et al., 2010) that formed due to the burial of an ice block beneath Lake Ilmiinjärvi flanking the esker core (cf. Fig. 3). However, based on the distinct trough-shaped reflections in seismic profile 2, this feature can also be interpreted as one of several channels present in the southwest end of profile 2. It is plausible that an MUKH structure was formed first due to burial of some ice in the sediments, followed by the collapse of the ice support in the southwest flank, leaving room for the channel formation.

\section{DISCUSSION}

\section{Geological setting of the sandstone depression}

The Satakunta sandstone basin has a gently sloping bedrock surface in the west and a steep and abrupt rise in the bedrock surface in the east (see Figs. 6, 8, 9). The bottom of the sandstone basin was too deep to be revealed by our seismic profiles, which reached depths of $-150 \mathrm{~m}$ asl (cf. Elo et al., 1993). The revealed brittle structures (brittle faults, fracture zones, and intense jointing) as well as open bending in the sandstone and the Svecofennian basement support the idea of the formation of the sandstone basin by oblique transtension (Pajunen and Wennerström, 2010). The eastern sandstone contact is steep and has no indication of a stepwise structure described for the sandstone basin margins (Kohonen and Rämö, 2005). A stepwise structure would indicate normal faulting on the basin margins, suggesting a northeast to southwest-oriented extension (rift model) not supported by the observations of Pajunen and Wennerström (2010). The dimensions of the Satakunta sandstone depression as well as the position and character of the sandstone contact also deviate from previous research (Palmu et al., 1994). This also means that the esker core does not follow the sandstone contact as suggested by Lindroos and colleagues (1983).

The low bedrock velocities $(3000-4000 \mathrm{~m} / \mathrm{s}$ ) suggest the presence of sandstone and the weathering or fracturing of the Svecofennian bedrock and do not indicate crystalline basement. It is plausible that a substantial amount of the bedrock surface within the Satakunta sandstone depression is broken, supported by the fracturing of mica gneisses and rapakivi granites adjacent to lithological contacts based on a refraction seismic profile north of the study area (Kurimo et al., 1992). The low bedrock velocities $(<4000 \mathrm{~m} / \mathrm{s})$ and the multiple bedrock reflections indicate a zone of fractured bedrock at the contact of the rapakivi granite to granodiorite and granite close to the notheast end of profile 1 (cf. Figs. 2 and 8 ). The horizontal reflection packages within the sandstone represent a laccolith structure related to the intrusion of the diabases into the sandstone. The diabase within the sandstone was also detected in electromagnetic soundings ca. $10 \mathrm{~km}$ southwest of our study area (Elo and Pirttijärvi, 2010).

The characteristics of the bedrock in the sandstone depression area reflect the development of the sandstone basin until the intrusion of the diabases into the sandstone (1250-1270 Ma) (Pajunen and Wennerström, 2010). The basin evolution between $1250 \mathrm{Ma}$ and the Holocene is poorly known. The basin's present form is due to erosion that occurred after the intrusion of the diabases and rapakivi granite. The exact roles glaciations and meltwater processes played in the shaping of the sandstone depression are unknown. The sandstone was eroded by the glacier and transported beneath and within the glacier ice. This material was transported toward the subglacial tunnel when its walls were melting (cf. Shreve, 1985) and deposited into the esker forming within the tunnel. This explains the high amount of sandstone clasts present in the Säkylänharju-Virttaankangas esker sediments (Mäkinen, 2003a). The rate of this erosion is unclear, as is whether it took place only during deglaciation or during earlier glacial stages/glaciations.

\section{Stratigraphy and depositional stages of the glaciofluvial complex}

The Satakunta sandstone depression includes 100-m-thick interlobate esker deposits overlying bedrock. These deposits are sand dominated, and gravels are present mostly in the southwest flank and at the bottom of the depression similar to the gravels on top of the sedimentary bedrock in the Muhos Formation area (Paalijärvi, 2010). Only one drill hole (REF-2017) revealed a till bed above the bedrock. The reflections of the bouldery till and solid sandstone bedrock were blended at $950-1250 \mathrm{~m}$ on profile 1 (see Fig. 8b), preventing the interpretation of the till bed on the bottom of the bedrock depression. The boulder-rich till detected in reference drill hole REF-2017 may represent older glacial sediments that were later eroded by glaciofluvial processes (Fig. 11a). The boulder on top of the till bed overlain by sorted material (7.2-m gravel bed) could represent boulder lag. Similar coarse sediments below the esker core occur in the 200-300-m-wide Virttaankangas bedrock fracture zone (Maries et al., 2017). However, due to the presence of the beds on top of the bedrock along the bottom of the Köyliö sandstone depression and the low velocities $(2000-3000 \mathrm{~m} / \mathrm{s}$ ) close to those observed from broken bedrock or sandstone in the Suupohja area (Pitkäranta, 2013), these reflections may originate from heavily weathered and/or fractured bedrock.

The arch-shaped feature with convex reflections was interpreted as the esker core (cf. Pugin et al., 2009; Pugin et al., 
a)

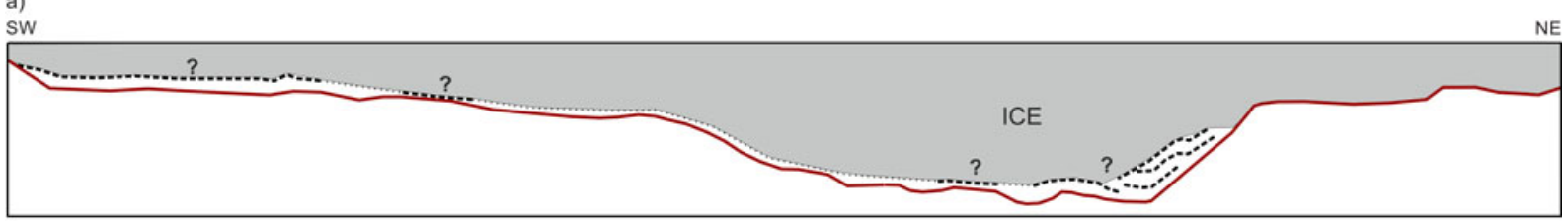

b)

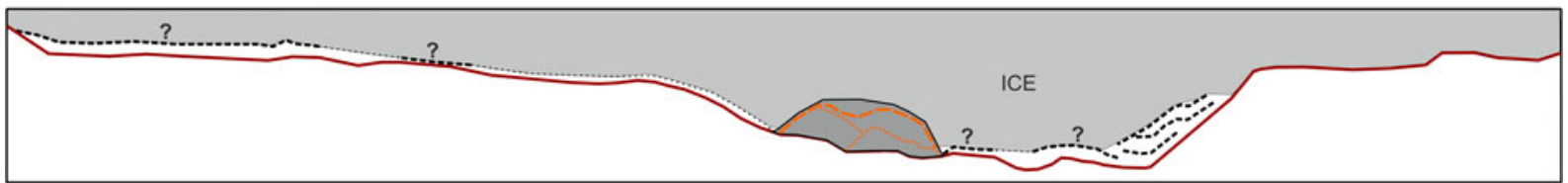

c)

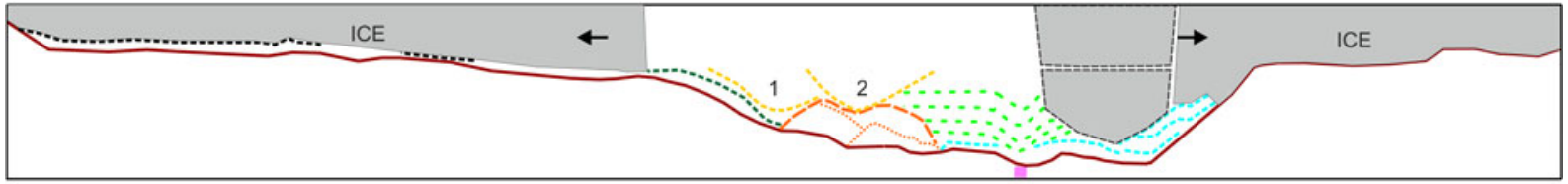

d)

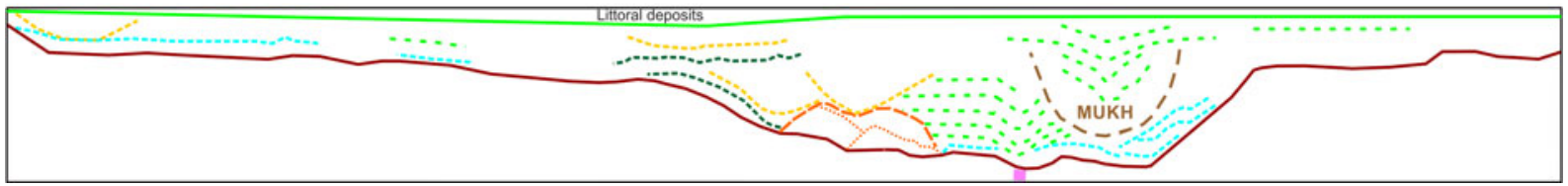

Figure 11. The depositional stages of the glaciofluvial complex in the sandstone depression. The colored lines refer to interpreted sedimentary structures in Figures 8 and 9. (a) The potential tunnel valley stage and sediments preceding deglacial esker deposition (black dashed lines). (b) Esker deposition in subglacial tunnel. (c) Expansion of the ice-walled re-entrant and burial of ice block (gray polygon with dashed margins) on the eastern side of the depression. Deposition of subaqueous outwash fan deposits on the flanks of the esker core. Outwash channel development on the flank of the esker (1) and on top of the esker due to a later proximal stage (2). (d) Deposition of sandy to silty sand distal outwash fan sediments on top of the buried outwash fan sediments and outside the sandstone depression. Melting of the buried ice block and collapse of the overlying outwash fan sediments. Deposition of littoral deposits on top of the glaciofluvial complex (above light green solid line).

2014a; Maries et al., 2017). The esker core does not follow the sandstone contact north of Lake Köyliönjärvi as stated by Lindroos and colleagues (1983) and Palmu and colleagues (1994). The hydrostatic regime is more stable along the flank compared to the deepest part of the depression where ice was likely thickest (cf. Shreve, 1972; Shreve, 1985; Syverson et al., 1994). Therefore, the esker core follows the shallower flank of the sandstone depression. Unlike the previous interpretation (Lindroos et al., 1983), there is no indication of the esker core leaning on the sandstone contact and having an asymmetrical form. Rather the esker core retains its arched shape. The uppermost parts of the coarse-grained esker core are at a depth of 50-60 m that is too deep for cost-effective ground water intake.

The esker core was deposited in a subglacial tunnel on the flank of the bedrock depression (see Fig. 11b). As the ice front retreated and the crevasse above the tunnel started to open (see Fig. 11c), the core was covered by a subaqueous outwash fan with abundant filled channels as the meltwater channel started to wander from side to side over the core (cf. Shreve, 1985). The filling of the depression floor with sediments played a role in the location of the channelized meltwater flow. The coarser outwash fan sediments became concentrated on the southwestern flank and the distal sandy outwash fan sediments on the eastern flank of the esker core. Mäkinen (2003a) also describes this for the glaciofluvial deposits along the same interlobate system southeast of Lake Köyliönjärvi. The steep eastern flank of the depression influenced the position of the esker core as well as the direction of the flanking subaqueous fan channels (cf. Rust and Romanelli, 1975). Based on the interpretations of GPR profiles near the land surface and the shape of the western margin of the sandstone depression, the channels indicate paleoflow mostly to the south-southeast deeper in the depression and to the southwest closer to the land surface (cf. Fig. 3). Finally, the orientation and presence of the De Geer moraines support an inference of the widening of the interlobate environment toward the west. However, the paleoflow directions could not be determined for the channels found in the deeper parts of the sandstone depression. The Ränkimyssuo channel shown in both the GPR and HRSR profiles presents a continuous channel feature in the top part of the esker deposits. Its length (3-4 km), dimensions (200-250 m wide, 10-20 m deep), well-developed sedimentary structures observed from the GPR profiles, and position on top of the esker deposits indicate prolonged and steady channelized meltwater flow with aggrading subaqueous fan sediments during the last stages of the deposition of the glaciofluvial complex (see 
Fig. 11d). The ice-walled re-entrant maintained a relatively axial flow rather than permitting flow expansion toward the flanks of the glaciofluvial complex. This depositional stage could perhaps be compared with the interlobate ice-marginal crevasse deposits on the esker-fan deposits within the Säkylänharju-Virttaankangas glaciofluvial complex that forms a marked ridge on the Svecofennian basement rocks.

Some buried ice blocks within the sediments lateral to the esker core are interpreted to have led to the formation of the MUKH structures (cf. Fig. 11c). The buried ice blocks melted gradually within the sediment, leading to the collapse of overlying glaciofluvial sediments and littorally reworked sediments during the land uplift into the hole created by the melted ice (see Fig. 11d). After the removal of ice support from the southwest and the collapse of sediments, meltwaters diverted along the current Lake Ilmiinjärvi and formed channels. The large and deep MUKH structures present in the upper part of the profiles do not flank the esker core as distinctly in the Köyliö study area as in Virttaankangas (Maries et al., 2017). A more detailed interpretation of the MUKH structures is partly inhibited by the weaker reflections present in the upper part of the seismic sections. The fractured and calving margins of the interlobate glaciofluvial bay (cf. Mäkinen, 2003b) released abundant ice blocks and bergs into the bay. In addition, local observations have been made of sporadic bouldery till-like sediments near profile 2 and further north on top of the glaciofluvial deposits (Mäkinen and Ahokangas, 2012). This material is ice-rafted debris carried by icebergs, which calved off the floating ice in the Köyliö deep-water area.

\section{Depositional conditions within the sandstone depression}

The erosional history of the sandstone basin is poorly constrained before the onset of deglaciation and esker deposition. The thin and few sediment beds preceding esker formation indicate weak glacial erosion either prior to or during the Weichselian glaciation. This is in line with the 100-m-thick pre-Weichselian glacial deposits of the Suupohja region (e.g., Pitkäranta, 2013) $110 \mathrm{~km}$ north of Köyliö. The Suupohja region was in the Southern Ostrobothnian interlobate region north of the Baltic Sea ice lobe (Punkari, 1980) where late-stage streamlined ice-flow forms and ice-marginal deposits are lacking. The pre-Late Weichselian sediments were preserved from glacial erosion (Pitkäranta, 2013). The Baltic Sea ice lobe divided into two separate and differently flowing ice lobes in southwest Finland (Punkari, 1980). The eastern sublobe (Loimaa lobe) terminated in shallower water with small supra-aquatic areas in the southeast. The western sublobe terminated in deeper water and flowed faster due to increased calving (Mäkinen, 2003b). This velocity difference between the sublobes enhanced the sediment and meltwater delivery into the interlobate area. In addition, the deep sandstone depression in the Köyliö area likely acted as a major storage for the glacial meltwaters as the focusing of (subglacial) meltwater is controlled by the location of bedrock valleys (Rattas, 2007).
The esker core deposition in the Köyliö area was likely preceded by the erosion of the existing deposits by the increased meltwater activity related to the interlobate glaciofluvial deposition as in the Virttaankangas fracture valley (Maries et al., 2017), where the continuation of deposits beneath the esker core could be more reliably confirmed.

A similar depositional setting occurs in the Muhos Formation (Breilin et al., 2006; Paalijärvi, 2010), which is the only known setting where eskers deposited on sedimentary rocks occur in major bedrock depressions in Finland. Globally, several examples are found of eskers interconnected with incised (sedimentary) bedrock valleys (e.g., Brennand and Shaw, 1994; Fisher et al., 2005; Jørgensen and Sandersen, 2006; Kehew and Kozlowski, 2007). The Köyliö depositional setting has similarities with the tunnel channel type $\mathrm{V}$ described by Kehew and Kozlowski (2007) where an upward-fining gravelly esker sediment sequence is found at the bottom of the tunnel channel. Kehew and Kozlowski (2007) envision the type $\mathrm{V}$ tunnel channel to form by subglacial meltwater erosion followed by the long persistence of a subglacial meltwater channel during ice retreat and esker deposition.

The shape of the sandstone depression resembles tunnel valleys, which often have steep and asymmetric sides (Ó Cofaigh, 1996). The gently sloping western flank and steep eastern flank of the Köyliö sandstone depression are similar to the narrower Virttaankangas bedrock fracture zone (200-300 m), which also has asymmetric flanks (Maries et al., 2017). The dimensions of the Köyliö sandstone depression (depth $0.1 \mathrm{~km}$, width $0.9 \mathrm{~km}$, and length $20 \mathrm{~km}$ ) are also in agreement with the dimensions of known tunnel valleys (Schumm and Shepherd, 1973; Ó Cofaigh, 1996; Brennand et al., 2006; Gibling, 2006; Kristensen et al., 2007; Pugin et al., 2014a). Tunnel valleys typically show undulating or convex-up longitudinal profiles (Rattas, 2007), but this was not observed in the Köyliö study area or further north (Palmu et al., 1994). The bedrock characteristics are interpreted as having influenced the asymmetric profile of the sandstone depression: sandstone in the west was more prone to glacial erosion (cf. Kaitanen and Ström, 1978), while the basement rocks in the east were more resistant.

The tunnel valleys in Denmark formed during a few hundred years by multiple glacial meltwater outbursts related to several ice-marginal positions (Sandersen et al., 2009). The Köyliö study area has De Geer moraines and subaqueous fans as indications of ice-marginal positions, and the role of meltwater activity in influencing the morphology of the sandstone depression is plausible as the sandstone is easily erodible (cf. Kaitanen and Ström, 1978). Glacial erosion and the role of meltwater are possible mechanisms in tunnel valley formation (Brennand et al., 2006; Ó Cofaigh, 1996). The Köyliö sandstone depression ends shortly before the Kuivalahti-Säkylä tributary esker joining the extensive Säkylänharju-Virttaankangas interlobate glaciofluvial complex. The sandstone depression is also crosscut by another west-northwest to east-southeast-oriented major fracture zone south of Lake Köyliönjärvi (Palmu et al., 1994). This 
fracture zone runs along the northern flank of the Säkylänharju-Virttaankangas glaciofluvial complex. The Köyliö sandstone depression and the adjacent crosscutting fracture zone acted as a major meltwater channel feeding substantial amounts of meltwater (cf. Lindroos, 1975) and sediment into the Säkylänharju-Virttaankangas interlobate glaciofluvial complex. The 20-30- m beds of sorted sediments (gravels overlain by silty sands) beneath the esker core in the northwest part of Säkylänharju represent preexisting deposits partly incised by subglacial tunnel flow during the last phase of deglaciation (Mäkinen, 2003a). These beds may represent the eroded tunnel valley sediments deposited into the major fracture zone by the meltwater flows.

The tunnel valley origin of the sandstone depression cannot be confirmed with the existing evidence. The roles of the glacial erosion and meltwaters in shaping the sandstone depression morphology are acknowledged and should be investigated further, as implied by thick sorted sediments below the esker core in the southeast end of the sandstone basin (Mäkinen, 2003a).

\section{CONCLUSIONS}

The landstreamer-based high-resolution (2-4 m receiver and shot spacing) reflection and refraction seismic survey revealed the characteristics and stratigraphy of a bedrock depression infilled with interlobate glaciofluvial complex sediments in Köyliö, southwest Finland. The sandstone depression represents a geological setting with varying bedrock lithology and topography combined with the infilling interlobate glaciofluvial sediments of the Pori-Koski esker. For the first time, brittle structures (brittle faults, fracture zones, and intense joining) and open bending in the sandstone and the Svecofennian basement were revealed, supporting the formation of the sandstone basin by oblique transtension. In addition, we confirm the presence of a diabase laccolith within the sandstone, the steep nature of the sandstone contact, and a new interpreted position of the contact.

We defined the exact position of the esker core within the deep sandstone depression for the first time in detail. The position of the hydraulically conductive esker core was confirmed to be west of the sandstone contact, not to follow the contact, and to have an asymmetric form; this contrasts with the previous research. The sedimentary fill in the Köyliö area indicates development of repeated subaqueous fans above the esker core similar to those interpreted for the Säkylänharju-Virttaankangas interlobate glaciofluvial complex within the same glaciofluvial system but in a more bedrock-confined setting in deeper proglacial water. The study has defined the depth of the uppermost parts of the esker core (50-60 m), which permits improved assessment of the economic viability of ground water extraction from the esker core.

The glacial erosion of the sandstone is supported by the high amount of sandstone clasts in the SäkylänharjuVirttaankangas esker further southeast. The interlobate position, combined with a major bedrock depression, enhanced the collection of meltwaters into the depression and into the fracture system south of it. The depression acted as a major meltwater pathway contributing to the large size of the Köyliö and the Säkylänharju-Virttaankangas glaciofluvial complexes. The dimensions of the sandstone depression agree with known tunnel valleys, but we cannot confirm the tunnel valley origin of the depression. The roles of glacial erosion and meltwater in forming the morphology of the sandstone depression are acknowledged and should be investigated further. Our results confirm the suitability of the landstreamerbased HRSR survey for the research of thick glaciofluvial deposits and the underlying bedrock in the geological conditions of Finland.

\section{ACKNOWLEDGMENTS}

The authors acknowledge funding through the Trust 2.2 GeoInfra project (http://www.trust-geoinfra.se) and Formas project (252-2012-1907) under which the seismic landstreamer was developed. We thank reviewers Don Cummings and Robert Storrar for the constructive comments that improved the manuscript. Turku Region Water Ltd, Geological Survey of Finland (GTK), and University of Turku/Department of Geography and Geology sponsored the data acquisition and collaborated in this project. Elina Ahokangas was funded by the Finnish Cultural Foundation Satakunta Fund and the Doctoral Programme in Biology, Geography and Geology (University of Turku Graduate School). Graduate students from Uppsala University participated in the fieldwork, for which the authors are grateful. We thank A. Tryggvason (Uppsala University) for providing the PStomo_eq available for use for travel time tomography. GLOBE Claritas ${ }^{\mathrm{TM}}$ under license from the Institute of Geological and Nuclear Sciences Limited, Lower Hutt, New Zealand, was used to process the seismic data.

\section{REFERENCES}

Ahmad, J., Schmitt, D.R., Rokosh, C.D. Pawlowicz, J., 2009. Highresolution seismic and resistivity profiling of a buried Quaternary subglacial valley: Northern Alberta, Canada. Geological Society of America Bulletin, 121, 1570-1583.

Ahokangas, E., 2019. New insights into the sedimentologicalgeophysical research of interlobate glaciofluvial complexes in western Finland. Annales Universitatis Turkuensis Ser AII Biologica-Geographica-Geologica 356.

Ahokangas, E., Mäkinen, J., 2014. NeittamonnummenKöyliönjärven pohjavesiolosuhteet ja rakennetulkinta. (In Finnish). Interpretation report 28.10.2014.

Artimo, A., Saraperä, S., Puurunen, O., Mäkinen, J., 2010. The Turku Region Artificial Infiltration Project, Finland-Tools for Enhanced Aquifer Characterization. The 7th Annual International Symposium on Managed Aquifer Recharge (ISMAR). Abu Dhabi, October 9-13, 2010.

Barnett, P.J., Sharpe, D.R., Russell, H.A.J., Brennand, T.A., Gorrell, G., Kenny, F.M., Pugin, A., 1998. On the origin of the Oak Ridges Moraine. Canadian Journal of Earth Sciences, 35, 1152-1167.

Boulton, G.S., Dongelmans, P., Punkari, M., Broadgate, M., 2001. Palaeoglaciology of an ice sheet through a glacial cycle: the European ice sheet through the Weichselian. Quaternary Science Reviews 20, 591-625. 
Breilin, O., Paalijärvi, M., Valjus, T., Huotari, T., Miettunen, A., 2006. Kempeleenharjun geologinen rakenneselvitys Pitkänaronkankaan ja Tuohinon välillä. (In Finnish). Geological Survey of Finland Archive report 25/2017.

Breilin, O., Putkinen, N., 2012. Limingan Vesikari-syvin maaperäkairaus Suomessa. Geologi, 64, 100-103.

Brennand, T.A., Russell, H.A.J., Sharpe, D., 2006. Tunnel channel character and evolution in southern Ontario. In: Knight, P.G. (Ed.), Glacier Science and Environmental Change. Blackwell Publishing Ltd., pp. 37-39.

Brennand, T.A., Shaw, J., 1994. Tunnel channels and associated landforms, south-central Ontario: their implications for ice-sheet hydrology. Canadian Journal of Earth Sciences, 31, 505-522.

Brennand, T.A., Shaw, J., 1996. The Harricana complex, Abitibi region, Quebec: their implications for ice-sheet meltwater regime and ice sheet dynamics. Sedimentary Geology, 102, 221-262.

Brodic, B., Malehmir, A., Juhlin, C., Dynesius, L., Bastani, M., Paul, H., 2015. Multicomponent broadband digital-based seismic landstreamer for near-surface applications. Journal of Applied Geophysics, 125, 227-241.

Brodic, B., Malehmir, A., Pugin, A., Maries, G., 2018. Threecomponent seismic land streamer study of an asker architecture through S- and surface-wave imaging. Geophysics, 83, B339B353.

Burschil, T., Buness, H., Tanner, D.C., Wielandt-Schuster, U., Gabriel, G., 2018. High-resolution reflection seismics reveal the structure and the evolution of the Quaternary glacial Tannwald Basin. Near Surface Geophysics, 16, 593-610.

Clayton, L., Attig, J.W., Mickelson, D.M., 1999. Tunnel Channels Formed in Wisconsin During the Last Glaciation. Geological Society of America (Special Paper) 337, 69-82.

Ó Cofaigh, C., 1996. Tunnel valley genesis. Progress in Physical Geography, 20, 1-19.

Cummings, D.I., Gorrell, G., Guildbault, J.-P., Hunter, J.A., Logan, C., Ponomarenko, D., Pugin, A.J.-M., Pullan, S.E., Russell, H.A.J., Sharpe, D.R., 2011. Sequence stratigraphy of a glaciated basin fill, with a focus on esker sedimentation. GSA Bulletin 123, 1478-1496.

Cummings, D.I., Russell, H.A.J., 2007. The Vars-Winchester esker aquifer, South Nation River watershed, Ontario. Geological Survey of Canada Open-File Report 5624, 68 p.

Elminen, T., Airo, M.-L., Niemelä, R., Pajunen, M., Vaarma, M., Wasenius, P., Wennerström, M., 2008. Fault structures in Helsinki area, southern Finland. Geological Survey of Finland, Special Paper 47, 187-213.

Elo, S., 1976. An Interpretation of a recently measured gravity profile across the Jotnian Sandstone Formation in southwestern Finland. Geological Survey of Finland archive report Q20/21/1976/1. 11 p.

Elo, S., Kuivamäki, A., Kurimo, M., Palmu, J.-P., Siivonen, M., 1993. Mynämäen-Laitilan-Pyhärannan harjuselvitys: GTK:n kesällä 1993 suorittamat tutkimukset. Final report 21.11.1993. Geological Survey of Finland, Espoo.

Elo, S., Pirttijärvi, M., 2010. Satakunnan painovoimatutkimukset. Summary: Gravity investigations in Satakunta. Geological Survey of Finland, Report of Investigation, 183, 65-104.

Eronen, M., Haila, H., 1990. The main ancient shorelines. In: Alalammi, P. (Ed.), Atlas of Finland. Folio 123-126 Geology. National Board of Survey and Geographical Society of Finland, p 17.

Fisher, T.G., Jol, H.M., Boudreau, A.M., 2005. Saginaw Lobe tunnel channels (Laurentide Ice Sheet) and their significance in south-central Michigan, USA. Quaternary Science Reviews, 25, 2375-2391.
Geological Survey of Finland, 1973. Seismiset luotaukset karttalehdellä 1134 09; linjat L1 Koomankangas, L2, L3 ja L4 (Järilänvuori). [Seismic soundings on map sheet 1134 09; lines L1, Koomankangas, L2, L3 and L4 (Järilänvuori)].

Gibling, M., 2006. Width and Thickness of Fluvial Channel Bodies and Valley Fills in the Geological Record: A Literature Compilation and Classification. Journal of Sedimentary Research, 76, 731-770. DOI:10.2110/jsr.2006.060.

Gruszka, B., Morawski, W., Zieliński, T., 2012. Sedimentary record of a Pleistocene ice-sheet inter-lobate zone (NE Poland). Geologos, 18, 65-81.

Heikkinen, P.J., Korja, A., Aaro, S., 1998. Bothnian Sea-a Mesoproterozoic extensional basin. Annales Geophysicae, 17, C61.

Hooke, R.L., Jennings, C.E., 2006. On the formation of the tunnel valleys of the southern Laurentide Ice Sheet. Quaternary Science Reviews, 25, 1364-1372.

Hughes, A.L.C., Gyllencreutz, R., Lohne, Ø.S., Mangerud, J., Svendsen, J.I., 2016. The last Eurasian ice sheets-a chronological database and time-slice reconstruction, DATED-1. Boreas 45, 1-45.

Huuse, M., Piotrowski, J., Lykke-Andersen, H. 2003. Geophysical investigations of buried Quaternary valleys in the formerly glaciated NW European lowland: Significance for groundwater exploration. Journal of Applied Geophysics, 53, 153-157.

Johansson, S., Taanila, P., 1975. Kokemäen vedensiirtosuunnitelma. Pitkäjärven kallionäytekairaukset. Geotek Oy.

Jørgensen, F., Sandersen, P.B.E., 2006. Buried and open tunnel valleys in Denmark - erosion beneath multiple ice sheets. Quaternary Science Reviews, 25, 1339-1363.

Kaitanen, V., Ström, O., 1978. Shape development of sandstone cobbles associated with the Säkylä-Mellilä esker, southwest Finland. Fennia, 155, 23-67.

Kehew, A.E., Kozlowski, A.L., 2007. Tunnel channels of the Saginaw lobe, Michigan, USA. In: Johansson, P., Sarala, P., (Eds), Applied Quaternary research in the central part of glaciated terrain. Geological Survey of Finland, Special Paper 46, pp. 69-78.

Kleman, J., Hättestrand, C., Borgström, I., Stroeven, A., 1997. Fennoscandian palaeoglaciology reconstructed using a glacial geological inversion model. Journal of Glaciology 43, 283-299.

Kohonen, J., Pihlaja, P., Kujala, H., Marmo, J., 1993. Sedimentation of the Jothnian Satakunta sandstone, western Finland. Geological Survey of Finland Bulletin 369.

Kohonen, J., Rämö, O.T., 2005. Sedimentary rocks, diabases, and late cratonic evolution. In: Lehtinen, M., Nurmi, P.A., Rämö, O.T., (Eds), Precambrian geology of Finland. Key to the evolution of the Fennoscandian Shield. Developments in Precambrian Geology 14. Amsterdam: Elsevier, 563-603.

Kristensen, T.B., Plotrowski, J.A., Huuse, M., Clausen, O.R., 2007. A morphometric analysis of tunnel valleys in the eastern Northern Sea based on 3D seismic data. Journal of Quaternary Science, 22, 801-815.

Kujansuu, R., Kurkinen, I., Niemelä, J., 1995. Glaciofluvial deposits in Finland. In: Ehlers, J., Kozarski, S., (Eds), Glacial deposits in North-East Europe. A. A. Balkema, Rotterdam, pp. 77-84.

Kurimo, M., Elo, S., Mattson, A., 1992. Kolsi-Kauttua säätötunnelin geofysikaalinen linjaselvitys, kohteet Pitkäjärvi ja Kalmeenkulma. 12 s. Geological survey of Finland, unpublished report.

Lindroos, P., 1975. Raportti maaperäkartoituksesta vuonna 1975 Porin 1143 karttalehden alueella. 13 p. (In Finnish). Geological Survey of Finland, Archive report P13.1.031.

Lindroos, P., Hyyppä, J., Stén, C., Tuittila, H., 1983. Geological map of Finland 1: 100 000. Explanation to the maps of 
Quaternary deposits. Sheet 1132 and 1134. Rauman ja Kokemäen seudun maaperä. (Summary: Quaternary deposits in the Rauma and Kokemäki map-sheet areas). Geological Survey of Finland, Espoo.

Lundqvist, J., 1989. Late glacial ice lobes and glacial landforms in Scandinavia. In: Goldwaith, R.P., Matsch, C.L., (Eds), Genetic classification of glacigenic deposits. A.A. Balkema, Rotterdam, pp. 217-226.

Mäkinen, J., 2003a. Time-transgressive deposits of repeated depositional sequences within interlobate glaciofluvial (esker) sediments in Köyliö, SW Finland. Sedimentology, 50, 327-360.

Mäkinen, J., 2003b. Development of depositional environments within the interlobate Säkylänharju-Virttaankangas glaciofluvial complex in SW Finland. Annales Academiae Scientiarum Fennicae. Geologica-Geographica 165.

Mäkinen, J., 2004. The sedimentology and depositional history of the Säkylänharju-Virttaankangas interlobate glaciofluvial complex in SW Finland. Annales Universitatis Turkuensis Ser AII Biologica Geographica Geologica 173.

Mäkinen, J., Ahokangas, E., 2012. Kokemäen Koomankankaan vedenhankinta-alueen sedimentologiset olosuhteet/maatutkaaineiston rakennetulkinta. (In Finnish) Report 31.10.2012.

Malehmir, A., Andersson, M., Lebedev, M., Urosevic, M., Mikhaltsevitch, V., 2013a. Experimental estimation of velocities and anisotropy of a series of Swedish crystalline rocks and ores. Geophysical Prospecting, 61, 153-167.

Malehmir, A., Andersson, M., Mehta, S., Brodic, B., Munier, R., Place, J., Maries, G., Smith, C., Kamm, J., Bastani, M., Mikko, H., Lund, B., 2016. Post-glacial reactivation of the Bollnäs fault, central Sweden - a multidisciplinary geophysical investigation. Solid Earth, 7, 509-527.

Malehmir, A., Saleem, U.M., Bastani, M., 2013b. High-resolution reflection seismic investigations of quick-clay and associated formations at a landslide scar in southwest Sweden. Journal of Applied Geophysics, 92, 84-102.

Maries, G., Ahokangas, E., Mäkinen, J., Pasanen, A., Malehmir, A., 2017. Interlobate esker architecture and related hydrogeological features derived from a combination of high-resolution se reflection seismics and refraction tomography, Virttaankangas, southwest Finland. Hydrogeology Journal, 25, 829-845.

Miall, A.D., 1985. Architectural-element analysis: a new method of facies analysis applied to fluvial deposits. Earth Science Reviews, 22, 261-308.

Paalijärvi, M., 2010. Muhoksen Karho-ojankankaan—Lantonkankaan alueen geologia ja pohjavesipotentiaali. Geological Survey of Finland, Report of Investigation 17.9.2010.

Pajunen, M., Airo, M.-L., Elminen, T., Mänttäri, I., Niemelä, R., Vaarma, M., Wasenius, P., Wennerström, M., 2008. Tectonic evolution of the Svecofennian crust in southern Finland. Geological Survey of Finland, Special Paper, 47, 15-160.

Pajunen, M., Airo, M.-L., Wennerström, M., Niemelä, R., Wasenius, P., 2001. Preliminary report: The "Shear zone research and rock engineering" project, Pori area, south-western Finland. Geological Survey of Finland, Special Paper, 31, 7-16.

Pajunen, M., Wennerström, M., 2010. Satakunnan hiekkakiven hauraiden rakenteiden kehityksestä. Development of brittle structures in the Satakunta sandstone. Geological Survey of Finland, Report of Investigation 183, 11-63.

Palmu, J.-P., Mattson, A., Valli, T., 1994. Köyliön-Ulvilan harjuselvitys. Geofysikaaliset ja geologiset tutkimukset. (Esker report of Köyliö-Ulvila. Geophysical and geological investigations.) Geological Survey of Finland, Archive report 15/2014.
Paterson, J.T., Cheel, R. J. 1997. The depositional history of the Bloomington complex, an ice-contact deposit in the Oak Ridges Moraine, southern Ontario, Canada. Quaternary Science Reviews 16, 741-753.

Paulamäki, S., Paananen, M., 2001. Structure and geological evolution of the bedrock at southern Satakunta, SW Finland. Extended abstract. Posiva Oy, Work Report, 2001-09. Posiva Oy, Helsinki.

Pitkäranta, R., 2009. Lithostratigraphy and age estimations of the Pleistocene erosional remnants near the centre of the Scandinavian glaciations in western Finland. Quaternary Science Reviews, 28, 166-180.

Pitkäranta, R., 2013. Lithostratigraphy and age of pre-Late Weichselian sediments in the Suupohja area, western Finland. Annales Universitatis Turkuensis Ser AII BiologicaGeographica-Geologica 283. Painosalama Oy, Turku.

Pokki, J., Kohonen, J., Lahtinen, R., Rämö, O. T., Andersen, T., 2013. Petrology and provenance of the Mesoproterozoic Satakunta formation, SW Finland. 47 p. Geological Survey of Finland, Report of Investigation 204.

Praeg, D., 2003. Seismic imaging of mid-Pleistocene tunnel-valleys in the North Sea Basin-high resolution from low frequencies. Journal of Applied Geophysics, 53, 273-298.

Pugin, A.J.-M., Larson T, Bergler S., McBride, J., Bexfield, C., 2004. Near-surface mapping using $\mathrm{SH}$-wave and $\mathrm{P}$-wave seismic land-streamer data acquisition in Illinois, U.S. Leading Edge 23, 677-682.

Pugin, A. J.-M., Mäkinen, J., Ahokangas, E., Artimo, A., Vanhala, H., Pasanen, A., Moisio, K., 2014b. High-resolution seismic reflection survey with landstreamer on the characterization of the Virttaankangas aquifer, SW Finland. In: Virtasalo, J., Tuusjärvi, M. (Eds.), Abstract book. $1^{\text {st }}$ Finnish National Colloqvium of Geosciences, Espoo, 19-20 March 2014. Geological Survey of Finland, Guide 58, pp. 63-64.

Pugin, A. J.-M., Oldenborger, G.A., Cummings, D.I., Russell, H.A.J., Sharpe, D. R., 2014a. Architecture of buried valleys in glaciated Canadian Prairie regions based on high resolution geophysical data. Quaternary Science Reviews, 86, 13-23.

Pugin, A. J.-M., Pullan, S.E., Hunter, J.A., Oldenborger, G.A., 2009. Hydrogeological prospecting using P- and S-wave landstreamer seismic reflection methods. Near Surface Geophysics, 7, 315-327.

Pugin, A.J.M., Pullan, S.E., Sharpe, D.R., 1999. Seismic facies and regional architecture of the Oak Ridges Moraine area, southern Ontario. Canadian Journal of Earth Sciences, 36, 409-432.

Pullan, S.E., Pugin, A., Hunter, J., 2007, Shallow seismic reflection methods for the delineation and hydrogeological characterization of buried eskers in eastern Ontario: Denver, Colorado, 20th Annual Symposium on the Application of Geophysics to Environmental and Engineering Problems (SAGEEP) Meeting, April 1-5, 2007.

Punkari, M., 1980. The ice lobes of the Scandinavian ice sheet during deglaciation in Finland. Boreas, 9, 307-310.

Rattas, M., 2007. Spatial distribution and morphological aspects of eskers and bedrock valleys in north Estonia: implications for the reconstruction of a subglacial drainage system under the late Weichselian Baltic Ice Stream. In: Johansson, P., Sarala, P., (Eds), Applied Quaternary research in the central part of glaciated terrain. Geological Survey of Finland, Special Paper 46, pp. 63-68.

Reynolds, J.M. 2011. An Introduction to Applied and Environmental Geophysics. 696 p. John Wiley \& Sons Ltd.

Russell, H.A.J., Arnott, R.W.C., 2003. Hydraulic-Jump and Hyperconcentrated-Flow Deposits of a Glacigenic Subaqueous 
Fan: Oak Ridges Moraine, Southern Ontario, Canada. Journal of Sedimentary Research, 73, 887-905.

Rust, B.R., Romanelli, R., 1975. Late Quaternary subaqueous outwash deposits near Ottawa. In: Jopling, A.V., McDonald, B.C., (Eds), Glaciofluvial and glaciolacustine sedimentation. Society of Economic Palaeontologist and Mineralogists Special Publication 23, 177-192.

Saarnisto, M., Salonen, V.-P., 1995. Glacial history of Finland. In: In: Ehlers, J., Kozarski, S., (Eds), Glacial deposits in North-East Europe. A. A. Balkema, Rotterdam, pp. 3-10.

Salas-Romero, S., Malehmir, A., Snowball, I., Lougheed, R., Hellqvist, M., 2015. Identifying landslide preconditions in Swedish quick clays-insights from integration of surface geophysical, core sample- and downhole property measurements. Landslides, 13, 1-19.

Sandersen, P. B. E., Jørgensen, F., Larsen, N. K., Westergaard, J. H., Auken, E., 2009. Rapid tunnel valley formation beneath the receding Late Weichselian ice sheet in Vendsyssel, Denmark. Boreas, 38, 834-851.

Santos, J.B., 2012. Late Wisconsinan glacial geomorphology of the Kent Interlobate Complex, Ohio, USA. Finisterra 47, 65-84.

Sauramo, M., 1929. Studies on the Quaternary varve sediments in southern Finland. Bulletin de la Commission Géologique de Finland 60 .

Schumm, S.A., Sheppard, R.G., 1973. Valley floor morphology: Evidence of subglacial erosion? Area, 5, 5-9.

Sharpe, D.R., Pullan, S.E., Warman, T.A., 1992. A Basin Analysis of the Wabigoon Area of Lake Agassiz, a Quaternary Clay Basin in Northwestern Ontario. Géographie physique et Quaternaire, 46, 295-309.

Shreve, R.L., 1972. Movement of water in glaciers. Journal of Glaciology, 11, 205-214.
Shreve, R.L., 1985. Esker characteristics in terms of glacier physics, Katahdin esker system, Maine. Geological Society of America, Bulletin, 96, 639-646.

Stroeven, A. P., Hattestrand, C., Kleman, J., Heyman, J., Fabel, D., Fredin, O., Goodfellow, B. W., Harbor, J. M., Jansen, J. D., Olsen, L., Caffee, M., Fink, D., Lundqvist, J., Rosqvist, G. C., Strömberg, B., Jansson, K. N., 2016. Deglaciation of Fennoscandia. Quaternary Science Reviews 147, 91-121.

Syverson, K.M., Gaffield, S.J., Mickelson, D.M., 1994. Comparison of esker morphology and sedimentology with former icesurface topography, Burroughs Glacier, Alaska. Geological Society of America Bulletin, 106, 1130-1142.

Thomas, G.S.P., Montaque, E., 1997. The morphology, øatigraphy and sedimentology of the Carstair esker, Scotland, U.K. Quaternary Science Reviews 16, 661-674.

Tikkanen, M. 1981. Georefief, its origin and development in the coastal area between Pori and Uusikaupunki, southwestern Finland. Fennia 159, 253-333.

Tremblay, T., Hunter, J., Lamontagne, C., Nastev, M., 2010. High Resolution Seismic Survey in a Contaminated Esker Area, Chateauguay River Watershed, Quebec. Canadian Water Resources Journal, 35, 417-432.

Tryggvason, A., Rognvaldsson S.T., Flovenz, O.G., 2002. Threedimensional imaging of the P- and S-wave velocity structure and earthquake locations beneath Southwest Iceland. Geophysical Journal International 151, 848-866.

Veräjämäki, A., 1998. Kokemäen kartta-alueen kallioperä. Summary: Pre-Quaternary rocks of Kokemäki map sheet area. Geological Map of Finland 1: 100 000. Explanation to the maps of Pre-Quaternary rocks. Sheet 1134. Geological Survey of Finland, Espoo. 